\title{
Political institutions and health expenditure
}

\author{
Johannes Blum ${ }^{1,2} \cdot$ Florian Dorn $^{1,2}$ (D) $\cdot$ Axel Heuer $^{3}$
}

Accepted: 23 November 2020 / Published online: 9 March 2021

(c) The Author(s) 2021

\begin{abstract}
We examine how political institutions influence health expenditure by using a panel of 151 developing and developed countries for the years 2000 to 2015 and four measures of democracy. Our pooled OLS analysis shows that democracies have 20-30\% higher government health expenditure relative to GDP than their autocratic counterparts. An instrumental variable approach which exploits the regional diffusion of democracy confirms the positive effect of democracy on government health expenditure. Panel fixed effects and event study models also suggest a positive within-country effect of democratization on government health expenditure within a short period after regime transition. Democratic rule, however, does not turn out to significantly influence private health expenditure compared to autocracies. We conclude that democracies may care more for their citizens and strive to decrease inequalities in the access to health care.
\end{abstract}

Keywords Event study · Democracy $\cdot$ Health expenditure $\cdot$ Development . Instrumental variable $\cdot$ Panel data

JEL Classification $\mathrm{I15} \cdot \mathrm{I} 18 \cdot \mathrm{H} 51 \cdot \mathrm{P} 50 \cdot \mathrm{C} 23 \cdot \mathrm{C} 26$

Florian Dorn

Dorn@ifo.de

Johannes Blum

Blum@ifo.de

Axel Heuer

Axel.Heuer@kfw.de

1 Ifo Institute, Poschingerstr. 5, 81679 Munich, Germany

2 University of Munich, 80539 Munich, Germany

3 KfW Group, KfW Development Bank, Palmengartenstr. 5-9, 60325 Frankfurt Am Main, Germany 


\section{Introduction}

Democracies are supposed to promote human well-being, while autocracies rather care about the well-being of the societal group which has political power and other elites whose loyalty needs to be ensured (Acemoglu and Robinson 2006). Theoretical models on the democracy-welfare nexus suggest that democracies provide more public goods and services, and generate more income redistribution than autocratic regimes (Meltzer and Richard 1981; McGuire and Olson 1996; Acemoglu and Robinson 2006). The median-voter theorem, for example, predicts larger public spending and an expansion of the welfare state in democracies to satisfy the needs of the electorate if economic inequality is large and the poor and middle class are the majority (Meltzer and Richard 1981).

Health care is a basic human need. Health infrastructure and access to health care are, however, costly. A national government therefore plays an important role in providing an adequate public healthcare system, especially for the poor and middle class. We expect that health expenditures of governments are higher in democracies than in autocracies as decision makers in democracies intend to satisfy the demand of the electorate for public health care. Figure 1 provides descriptive evidence for this hypothesis for high-income countries comparing democracies and autocracies which are at the same stage of economic development. We do, however, not expect that private health expenditures are larger in democracies than in autocracies because out-of-pocket health expenditures are primarily based on individuals' private health investment decisions and increased government health expenditures in democracies might even substitute private out-of-pocket health expenditures. ${ }^{1}$

We examine how political institutions influence government and private health expenditure by using pooled OLS, panel data, and event study models. Our panel consists of 151 developing and developed countries for the years 2000 to 2015 . We employ health expenditure data from the World Health Organization and use four democracy measures. We find that health expenditures of governments are indeed higher in democracies than in autocracies, while private health expenditures do not turn out to be significantly affected by the strength of democratic institutions. Our findings corroborate previous empirical studies which exploit cross-country variation and show that government health expenditure is larger in democracies than in autocracies (Avelino et al. 2005; Besley and Kudamatsu 2006; Gregorio and Gregorio 2013; Profeta et al. 2013).

Empirical literature on the relationship between political institutions and health expenditure is, however, scarce and not unambiguous. ${ }^{2}$ Scholars show a positive relationship in cross section studies, whereas panel fixed effects studies with small samples lack statistical significance. Besley and Kudamatsu (2006) show a positive

\footnotetext{
1 Note that the high-income autocracies in Fig. 1 are particularly oil exporting countries.

2 Empirical studies also examine how political institutions affect the size of government in general or government expenditure for other items of public spending. Results are, however, mixed (e.g., Habibi 1994, Lake and Baum 2001, Plümper and Martin 2003, Mulligan et al. 2004, Hausken et al. 2004, Avelino et al. 2005, Deacon 2009, Profeta et al. 2013).
} 
conditional relationship between established democracies and government health expenditure per capita for a cross section of 145 countries in the year 2000. Gregorio and Gregorio (2013) employ a cross-country approach for 159 countries in the year 2008 and confirm a positive conditional relationship between democracy and total and government health expenditure (per capita and relative to GDP). Profeta et al. (2013) examine the relationship between the strength of democratic institutions and indicators for public spending and taxation in a sample of 33 developing and low-income countries that have experienced a democratic transition during the period 1990-2005. The pooled OLS approach yields a U-shaped relationship between the strength of political institutions and public health expenditure (relative to GDP). This relationship, however, lacks statistical significance in a linear pooled OLS model and a panel model with country fixed effects. In a similar vein, Avelino et al. (2005) show a positive correlation between democracies and health spending which lacks significance in a fixed effects panel model for 19 Latin American countries between 1980 and 1999 .

Our empirical approach has some novel contributions compared to previous studies examining the effect of political institutions on health expenditure. Previous studies mainly use the composite index of the Polity IV dataset or even choose an arbitrary threshold score of this index to classify countries above as being democratic (see Besley and Kudamatsu 2006; Gregorio and Gregorio 2013; Profeta et al. 2013). The index is, however, highly controversial (see Cheibub et al. 2010; Plümper and Neumayer 2010). Moreover, definition and classification on the strength of democratic institutions may vary in different concepts. We therefore use four measures of democracy. Democracy measures may differ in whether a country is described to be a democracy or an autocracy and may therefore give rise to different empirical results. We moreover employ a large balanced panel of 151 developing and developed countries during the period from 2000 to 2015 and distinguish between the effect of democracy on both general government health expenditure and private ("out-of-pocket") health expenditure. Because of the rather short period of available health expenditure data from 2000 to 2015, we observe only little variation in democracy within countries during the observation period. We therefore follow related studies and estimate cross-country and panel data models which allow us to estimate both between- and within-country effects of democracy. In addition, we employ event study approaches to examine how health expenditures evolve before and after transition to democracies and vice versa.

Estimating the effect of democracy on health expenditures is likely to involve endogeneity problems, particularly because of unobserved characteristics (omitted variable bias), reverse causality, and measurement error in democracy measures. Previous empirical studies do not deal with the endogeneity problem and only provide conditional correlations between democracy and health expenditures. We overcome endogeneity concerns by using an instrumental variable (IV) approach which exploits geographical patterns and the diffusion of democratic regimes across countries. Similar to the approach of Acemoglu et al. (2019), we employ the average of the democracy scores of countries within the same region as an instrumental variable for the home country's democracy score. Our instrumental variable approach allows estimating an effect of democracy in the cross-country OLS approach. 


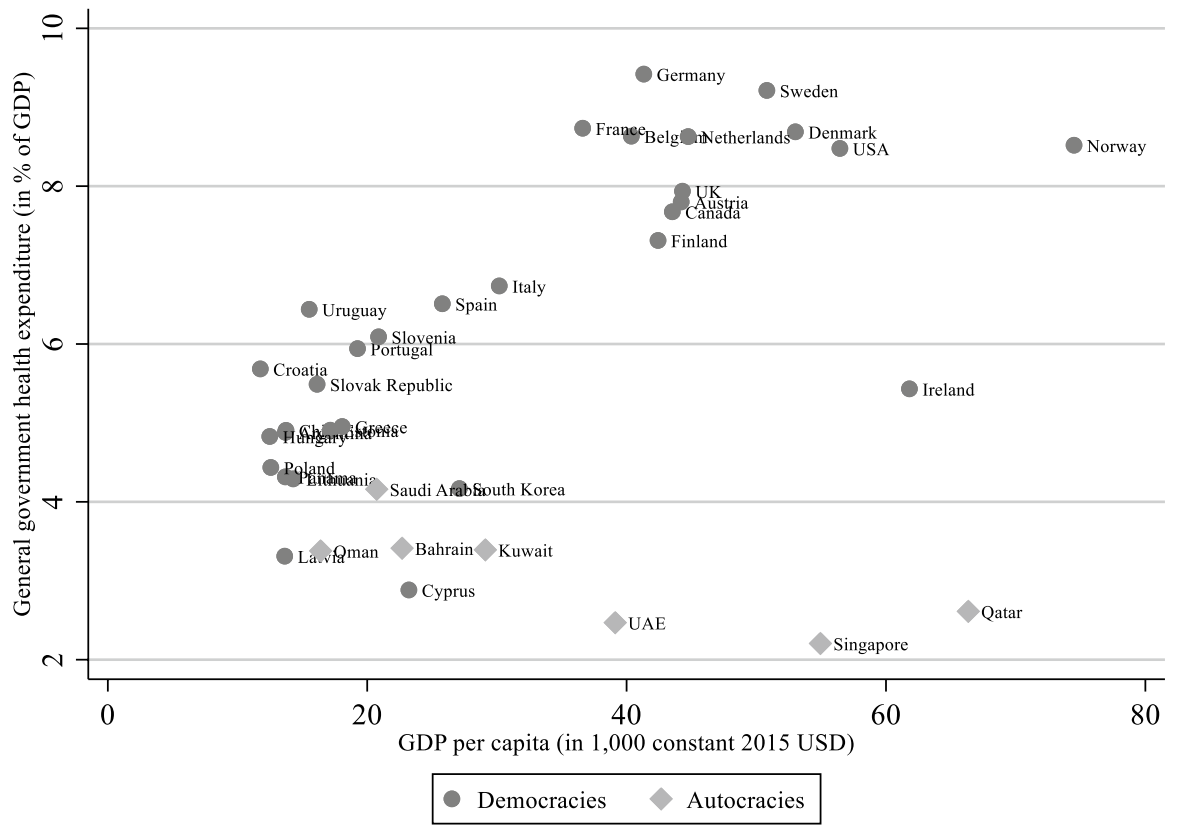

Fig. 1 Government Health Expenditure in Democracies and Autocracies in 2015 (high-income countries only). Luxembourg and Switzerland excluded as outlier

Our cross-country estimation results show a positive effect of democracy on general government health expenditure (relative to GDP) according to pooled OLS and IV estimates. Democratic governments spend relative to GDP about 20-30\% more on health than their autocratic counterparts, according to dichotomous democracy measures. The findings also suggest positive within-country effects in a panel fixed effects model. Panel fixed effect and event study results indicate that the difference in government health expenditure becomes visible within a rather short time period after regime transition. Our findings suggest a positive within-country effect of democratization of about $15-20 \%$ according to dichotomous democracy measures. Private health expenditures are positively related with democracy, but do not turn out to be significantly affected by the political regime. Our results suggest that democracies seem to care for their people by using government health expenditures to increase public health.

\section{Data and descriptive evidence}

Political institutions are difficult to measure: the type of measure (e.g., dichotomous or continuous), the institutions regarded as critical for a democracy and the aggregation of information to one single measure heavily influence whether a country is described to be a democracy or an autocracy. Using individual democracy measures can therefore give rise to different empirical results. Scholars suggest employing 
individual measures of democracy when institutional determinants of government spending are examined (Blum 2021). ${ }^{3}$ We therefore use four measures of democracy: first, the dichotomous democracy measure by Bjørnskov and Rode (2019), which is an update of the Democracy-Dictatorship dataset by Cheibub et al. (2010). Second, the Polity IV index by Marshall et al. (2018), which is an update of the Polity III dataset by Jaggers and Gurr (1995). Third, the Dichotomous Support Vector Machines Democracy Index (DSVMDI) and, fourth, the Continuous Support Vector Machines Democracy Index (CSVMDI) by Gründler and Krieger (2016, 2018), which are both based on machine learning techniques to classify the strength of democratic institutions. Previous studies examining the relationship between political institutions and health expenditure primarily used the Polity IV index. ${ }^{4}$ Table 5 in Appendix shows which countries experience regime transitions according to the four measures.

The dichotomous democracy measure by Bjørnskov and Rode (2019) provides a clear-cut classification of democracy and autocracy. Countries are specified as a democracy if chief executive and legislature are both popularly elected, more than one party competes in the elections and the power has alternated under the identical electoral rules as when the predecessor assumed office (Cheibub et al. 2010, pp. 69-71). Bjørnskov and Rode (2019) label regime changes to democracy or autocracy for the respective year in case the change occurred in the first half of the year, and for the subsequent year otherwise. The Polity IV index by Marshall et al. (2018) is a composite index measuring autocracy and democracy on a scale ranging from -10 to +10 . The Polity IV measure consists of two composite indices for autocracy and democracy-each ranging between 0 and 10. Both indices account for the competitiveness and openness of executive recruiting, the constraints on the chief executive and the competitiveness and regulation of political participation. The scores all describe political institutions as of the end of the year. We introduce the Polity IV index into the regression with a time lag; the variable thus describes the Polity IV index as of the beginning of each year and allows for at least one calendar year for budgetary adjustments to arise after a change in the Polity IV score. ${ }^{5}$ The Polity IV score describes political institutions rather than democracy as such because no clear-cut threshold Polity IV score exists above which a country can be regarded as a democracy. The two democracy measures developed by Gründler and Krieger $(2016,2018)$ are both based on machine learning techniques. The Dichotomous Support Vector Machines Democracy Index (DSVMDI) $)_{\text {it }}$ assumes a value of one for a democracy and zero otherwise; the Continuous Support Vector Machines

\footnotetext{
3 See Potrafke $(2012,2013)$ on how using different democracy measures can change established results.

${ }^{4}$ Gregorio and Gregorio (2013) and Profeta et al (2013) employed the composite Polity IV index. Besley and Kudamatsu (2006) used a dichotomous democracy measure and specified a country as democratic if the Polity IV score is positive. As an exception, Avelino et al. (2005) use the Polity IV index for robustness tests. Their main indicator is a dichotomous measure based on Alvarez et al. (1996), which Cheibub et al. (2010) and Bjørnskov and Rode (2019) have further developed.

5 We apply the variable "Polity2" from the Polity IV dataset which indicates intermediate values instead of missing values during transition.
} 
Democracy Index (CSVMDI) $)_{\text {it }}$ classifies countries along a continuum between zero and one. ${ }^{6}$ These two democracy measures are lagged by one year, too.

Data on both government and private health expenditure are provided by the World Bank. The World Bank is, however, not the primary source as the data are collected by the World Health Organization in the WHO Global Health Expenditure database. We use general government health expenditure and private ("out-ofpocket") health expenditure, both relative to a country's GDP, as dependent variables. The availability of data on health expenditure allows us to assemble a panel with 151 developing and developed countries for the years 2000 to 2015 .

Since our sample includes both developing and developed countries, both descriptive findings and estimation results might be biased if we ignore differences in the level of economic development. We therefore consider GDP per capita in all figures and empirical models. Most high-income countries have been democracies during the observation period, while democracies are few in the group of low-income countries. Given the rather short observation period from 2000 to 2015 , variation in democracy is much more pronounced between countries than within countries.

Figure 2 shows general government health expenditure (relative to GDP) in the year 2015 for all countries which have been permanent democracies or autocracies throughout the observation period. The fitted lines for democracies and autocracies indicate that for a given level of economic development, democracies have higher government health expenditure than their autocratic counterparts. The slopes of the fitted lines indicate that higher GDP per capita is related to increasing government health expenditure (relative to GDP). Countries thus experience an income effect on government health expenditure (relative to GDP) which is, however, much more pronounced for democracies than for autocracies.

We expect the differences between democracies and autocracies to be smaller or nonexistent for private health expenditure. Figure 3 shows private health expenditure (relative to GDP) for permanent democracies and autocracies for the year 2015 . The fitted lines for both regime types do not indicate that differences in private health expenditure are large between democracies and autocracies at the same level of economic development. Both fitted lines, however, exhibit a negative slope which suggests that the out-of-pocket expenditure share of private households for health purposes decreases when income per capita increases, in democracies and autocracies notwithstanding.

Differences in health expenditure between democratic and autocratic regimes also exist within countries. These differences can, however, only be observed for the limited number of countries which experienced regime transitions during the observation period. Georgia, for example, increased government health expenditure relative to GDP after becoming a democracy in 2004 from 1.2 to $3.1 \%$ in 2015 ; private

\footnotetext{
${ }^{6}$ Even though the dichotomous democracy measure by Gründler and Krieger $(2016,2018)$ and the democracy measure by Bjørnskov and Rode (2019) are both dummy variables, these two democracy measures show considerable differences in whether they classify a country as a democracy (particularly for African and Asian-Pacific countries). Table 5 in Appendix shows a list of the 151 countries included in the panel and indicates whether countries experienced variation in the four democracy measures during the observation period.
} 
health expenditure relative to GDP dropped from 6.7 to $4.7 \%$ within the same time. Tunisia, an example of the Arab spring, increased government health expenditure relative to GDP from around $2.9 \%$ in the years before democratic transition in 2011 to around $3.9 \%$ in the years after; private health expenditure relative to GDP only slightly increased from around $2.5 \%$ to around $2.8 \%$ after democratic transition.

Table 6 in Appendix shows summary statistics for the entire sample as well as for the subsets of permanent democracies and permanent autocracies during the period 2000-2015 according to the dichotomous democracy measure by Bjørnskov and Rode (2019). Summary statistics support the findings of Figs. 2 and 3. The mean values for government health expenditure (relative to GDP) are $4.2 \%$ for democracies and $2.0 \%$ for autocracies - a difference of 2.2 percentage points; the difference in mean values for private health expenditure (relative to GDP) is much less pronounced (2.5 vs. $2.4 \%$ ). The summary statistics also indicate strong differences in GDP per capita as well as in the demographic control variables old age population (population share of individuals age 65 and older) and young age population (population share of individuals between age 0 and 14), and the globalization level between democracies and autocracies: democracies are economically more developed, more globalized, and consist of older societies on average. ${ }^{7}$ Unconditional correlations of these variables are shown in Table 7 in Appendix.

\section{Pooled OLS and IV strategy}

\subsection{Pooled OLS and instrumental variable (IV) models}

We first estimate a pooled cross-country OLS model for the years 2000-2015:

$$
y_{\mathrm{it}}=\beta \text { Democracy measure }_{\mathrm{it}-1}+x_{\mathrm{it}-1} \delta+\varepsilon_{\mathrm{it}} \quad \text { with } t=2000, \ldots, 2015 .
$$

The dependent variable $y_{\text {it }}$ describes the natural logarithm of either government health expenditure (relative to GDP) or private health expenditure (relative to GDP)

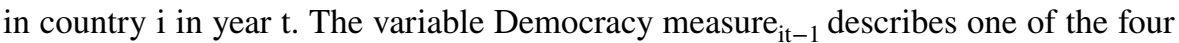
democracy measures applied in the empirical analysis in year $t-1$. The coefficient $\beta$ describes the effect of democracy on government or private health expenditure. The one-year time lag of the democracy measure allows for a reaction time until effects of budgetary decisions become effective and mitigates concerns of reverse causation. Standard errors are robust to heteroskedasticity.

The $1 \times \mathrm{K}$ vector $\boldsymbol{x}_{\mathbf{i t}-1}$ contains control variables. The parameters of the control variables are included in the $\mathrm{K} \times 1$ vector $\delta$. We include five control variables in

\footnotetext{
7 Though columns (2) and (3) of Table 6 in Appendix distinguish between countries which have been labeled as democracies and autocracies according to the democracy measure by Bjørnskov and Rode (2019), the summary statistics for the lag of this democracy measure indicate variation within the group of democratic and autocratic countries. This is based on the lagged value $(\mathrm{t}-1)$ of the democracy variable: Indonesia and Senegal have been labeled as autocracies in 1999 and as democracies from 2000 until 2015; Fiji has been labeled as a democracy in 1999 and as an autocracy from 2000 until 2015.
} 


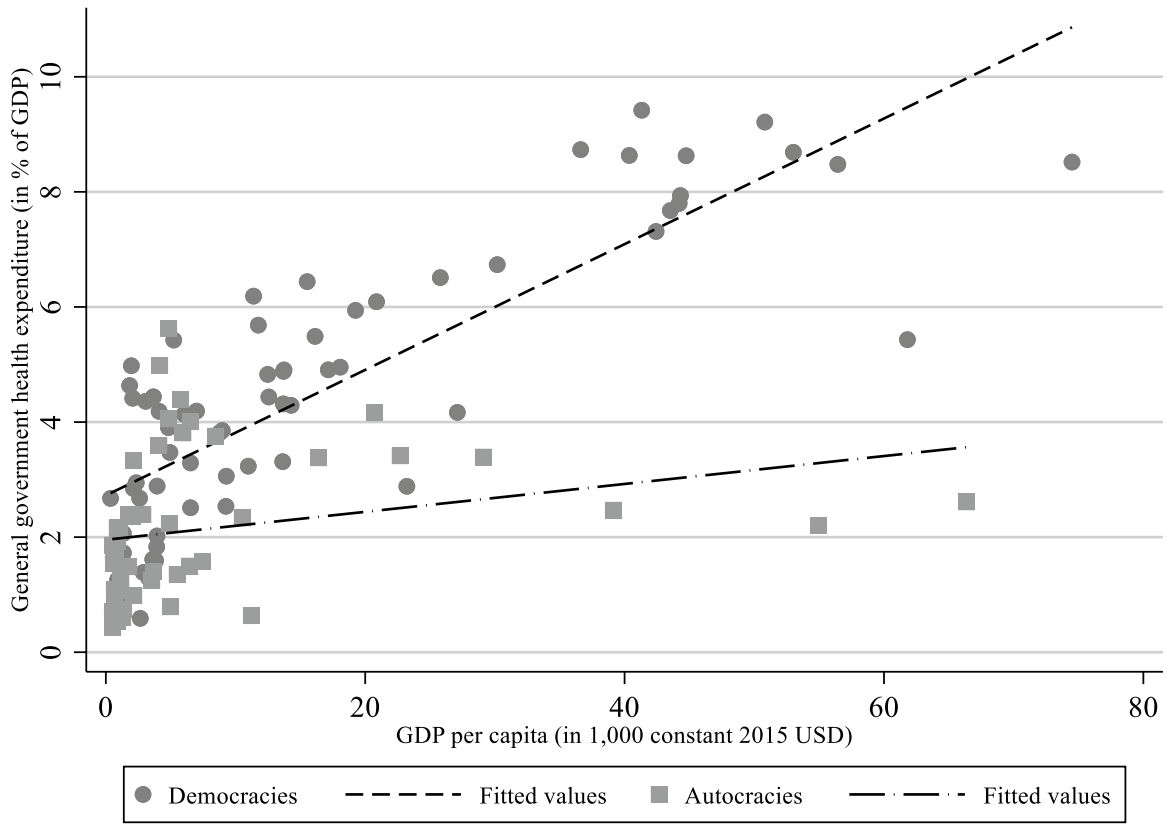

Fig. 2 Government Health Expenditure in Democracies and Autocracies in 2015 (all countries). Luxembourg and Switzerland excluded as outlier

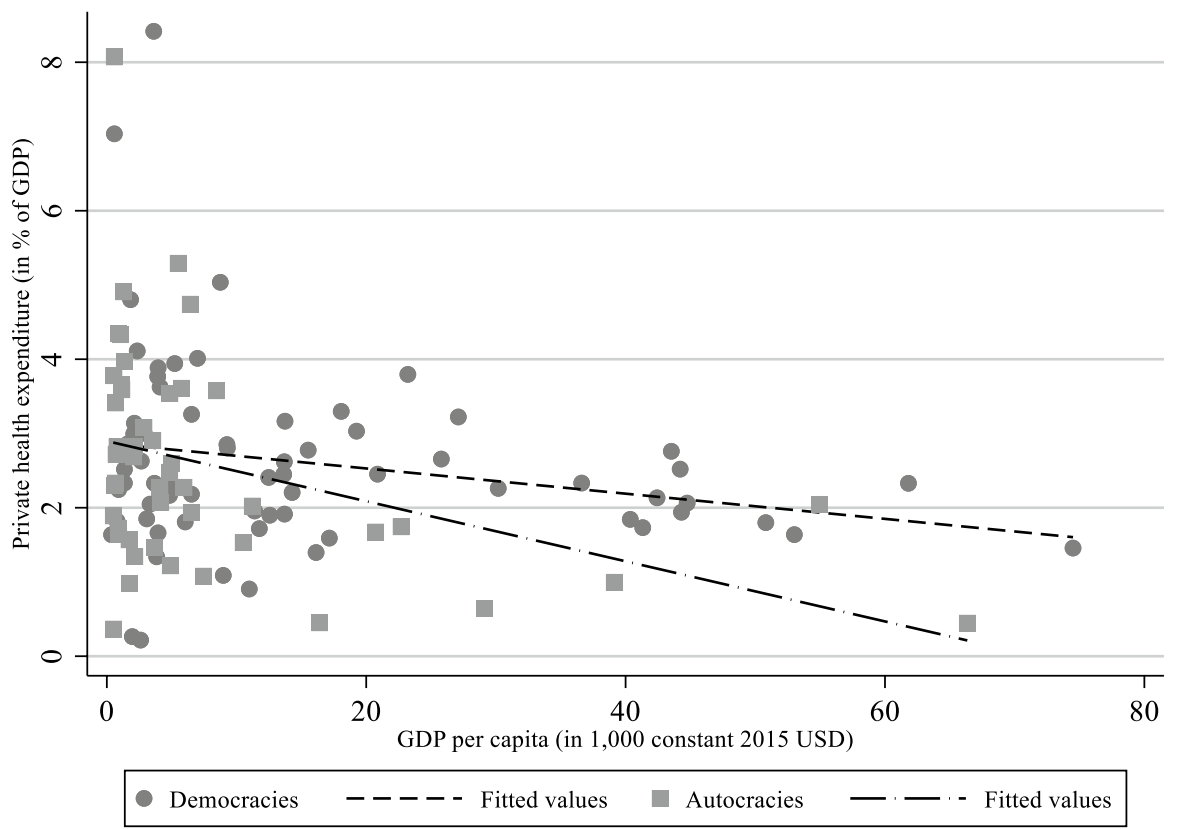

Fig. 3 Private Health Expenditure in Democracies and Autocracies in 2015 (all countries). Luxembourg and Switzerland excluded as outliers 
our baseline models: GDP per capita in constant (2015) US dollars, population, the population share of the old (individuals with age 65 or older), the population share of the young (individuals between age 0 and 14), and an index for the level of globalization. Omitting GDP per capita would likely give rise to biased estimates for the effect of democracy on health expenditure: on the one hand, GDP per capita is expected to directly affect budget compositions of governments and thus health expenditure shares (relative to GDP). On the other hand, economic development may affect democratic transition and political stability (Lipset 1959). Stable democracies and democratization are, moreover, likely to increase economic development (Acemoglu et al. 2019; Papaioannou and Siourounis 2008). Scholars have frequently shown that demographic indicators are relevant determinants of health expenditure (e.g., Gerdtham 1992; Barros 1998; Roberts 1999). We control for young and old age population shares because these age groups are expected to need more health care than the working age population and are likely to influence the size and patterns of health expenditure. Globalization is included as a control variable as the level of economic, social, and political openness likely influences both, social spending and political institutions. ${ }^{8}$ Previous studies have shown that GDP, globalization, and the composition of the population are relevant control variables (see Avelino et al. 2005, Besley and Kudamatsu 2006, Profeta et al. 2013). All control variables are lagged by one year. Data for GDP and for the demographic variables are provided by the World Bank and enter the regression in their natural logarithms. ${ }^{9}$ The level of globalization is measured by the KOF index of overall globalization, which is a composite index including the dimensions of economic, social, and political openness of countries (Gygli et al. 2019). ${ }^{10}$

Endogeneity issues are likely to arise in an empirical setup which estimates health expenditure as a function of democracy. There are three reasons for potential endogeneity of the democracy variable in our model: measurement errors in the democracy measure, omitted variable bias, and reverse causality. We have included several relevant control variables, but other unobserved characteristics might simultaneously determine both political institutions and health expenditure and thus give rise to biased estimates. Reverse causality might occur, for example, if poor average health status of the population and low public health provision give rise to regime changes. Moreover, errors in the measurement of democracy scores might bias the estimator toward zero and thus would underestimate the effect of democracy on health expenditure.

To deal with the endogeneity problems, we exploit the regional diffusion of democracy as an instrumental variable and, thus, follow the instrumental variable

\footnotetext{
${ }^{8}$ Globalization is discussed as a possible determinant of income inequality and of the budgetary composition of governmental policies (see Avelino et al. 2005, Dreher et al. 2008, Dorn et al. 2018, Dorn and Schinke 2018). The global diffusion of knowledge-facilitated by political, economic, and educational conditions - may well differently influence health outcomes in democracies and autocracies (see Deaton 2004, Bergh and Nilsson 2010, Welander et al. 2015).

9 As for the health expenditure data, the World Bank may, however, not be the primary source of the data: population data, for example, are collected by the United Nations.

10 The KOF index has been used in numerous empirical studies (see Potrafke 2015 for a survey).
} 
approach by Acemoglu et al. (2019). This instrument exploits geographical patterns of political institutions and "the diffusion of political regimes across countries in the same region and with common political histories" (Acemoglu et al. 2019, p. 51). We construct jackknifed democracy scores for the four democracy measures to describe democracy's regional diffusion. Countries are allocated to geopolitical regions $R$ according to their geographic proximity, similar cultures, and histories. The jackknifed democracy instrument $\mathrm{JDI}_{\mathrm{it}}$ for country $j$ in year $t$ is calculated as the average democracy score of all $n$ countries in country $j$ 's region $R_{j}$ except of the democracy score of country $j$ itself:

$$
\mathrm{JDI}_{i=j, t}=\frac{1}{n-1} \sum_{i \neq j, i \in R_{j}}^{n} \text { Democracy Measure }_{\mathrm{it}} .
$$

The jackknifed democracy measures are an arguably excludable instrument. The exclusion restriction requires that the instrument does not influence health expenditure directly or through other unobserved variables. Political developments and budget decisions in a country may well influence preferences of the population and budget decisions of the political regime in other countries within the same geopolitical region. It is reasonable to assume that health expenditure shares (relative to GDP) are affected by the political institutions of countries within the same region only via effects on own country's political institutions. One may argue that the exclusion restriction is not fulfilled if increased economic growth in a democracy has a spillover effect on the quality, price, and expenditure for health care in countries within the same geopolitical region. Spillover effects are, however, mitigated for two reasons: First, we include globalization as a control and thus capture increased trade, capital flows, migration, and information flows between countries, which might be the main channels for spillover effects apart from political adaptation. Second, we use health expenditure normalized by GDP as outcome variables and scholars have shown that the regional diffusion of the demand for democracy also occurs conditioned on GDP (Bonhomme and Manresa 2015).

Spatial diffusion of democratization might be, for example, more likely across countries in regions with similar cultures and histories and larger informational exchange (Acemoglu et al. 2019). Closer informational ties between countries increase the likelihood of the spread of political protests and regime changes (Ellis and Fender 2011; Aidt and Jensen 2014). Our first-stage regression results confirm these findings. The relevance of the IV depends on its conditional correlation with the respective democracy measure. The first-stage regression has the following form:

$$
\text { Democracy }_{\mathrm{it}}=\gamma \mathrm{JDI}_{\mathrm{it}-1}+x_{i, t-1} \theta+e_{\mathrm{it}} \quad \text { with } t=2000, \ldots, 2015 .
$$

The model includes the same set of control variables $\boldsymbol{x}_{\boldsymbol{i}, t-1}$ as in Eq. (1). The predicted values of the democracy measures from the first-stage regressions can be regarded as exogenous indices for whether a country is described as a democracy or an autocracy and replace the presumably endogenous democracy measure in Eq. (1). The second-stage regression of this two-stage least-squares (2SLS) approach for the cross-country model has the following form: 


$$
y_{\mathrm{it}}=\beta \text { Democracy }_{\mathrm{it}-1}+x_{\mathrm{it}-1} \delta+\varepsilon_{\mathrm{it}} \quad \text { with } t=2000, \ldots, 2015 .
$$

\subsection{Pooled OLS and IV results}

Tables 1 and 2 show pooled OLS and IV results for general government and private health expenditure (relative to GDP). We show OLS results of democracy conditioned on GDP per capita in Panel A and including the entire set of control variables as described by Eq. (1) in Panel B of Tables 1 and 2. Panel C of Tables 1 and 2 shows 2SLS estimation results and Panel D shows first-stage results of the jackknifed democracy instrument for each of the four democracy measures (results for the control variables in Panels C and D are not reported).

Democracy shows a positive and significant effect on general government health expenditure (relative to GDP) at the $1 \%$ level according to all four democracy measures in Panel A of Table 1. The estimates are slightly reduced in size once the model includes the full set of control variables in Panel B. The dichotomous democracy measures Democracy by Bjørnskov and Rode (2019) and the Dichotomous Support Vector Machines Democracy Index (DSVMDI) indicate that government health expenditure (relative to GDP) in democracies is $21 \%$ and $19 \%$ higher than in their autocratic counterparts. ${ }^{11}$ According to the Continuous Support Vector Machines Democracy Index (CSVMDI) democracies have 29\% higher government health expenditure (relative to GDP) than their autocratic counterparts (comparing hypothetical "perfect" democracies with a score of 1 with "perfect" autocracies with a score of 0 ). An additional score of one in the Polity IV index is associated with $2.1 \%$ more government health expenditure (relative to GDP).

The IV results in Panel $\mathrm{C}$ of Table 1 confirm the findings of a positive effect of democracy on government health expenditure. The estimates are statistically significant except for the Polity IV variable. ${ }^{12}$ The other democracy measures are statistically significant and larger than the OLS estimates. OLS results thus are likely to underestimate the effect of democracy on government health expenditure because of endogeneity issues as discussed in Sect. 3.1. As Acemoglu et al. (2019, p. 83) also state it, the larger IV estimates "may reflect a downward bias introduced by [...] unobservables or the possibility of attenuation in our previous estimates due to measurement error in the index of democracy." Using IV estimates, the effect of democratic rule on government health expenditure is 5.2 percentage points larger than pooled OLS estimates for the democracy measure (Democracy) by Bjørnskov and Rode (2019), and 0.5-1.3 percentage points larger for the machine learningbased democracy measures (DSVMDI, CSVMDI) by Gründler and Krieger (2016,

\footnotetext{
11 Note that the percentage impact of democracy, i.e., when the dummy switches to one, is calculated as $100[\exp (0.192)-1]=21.2$.

12 This is in line with the results by Profeta et al. (2013), who do not find significant linear relationships by using the Polity IV scores as democracy measure.
} 


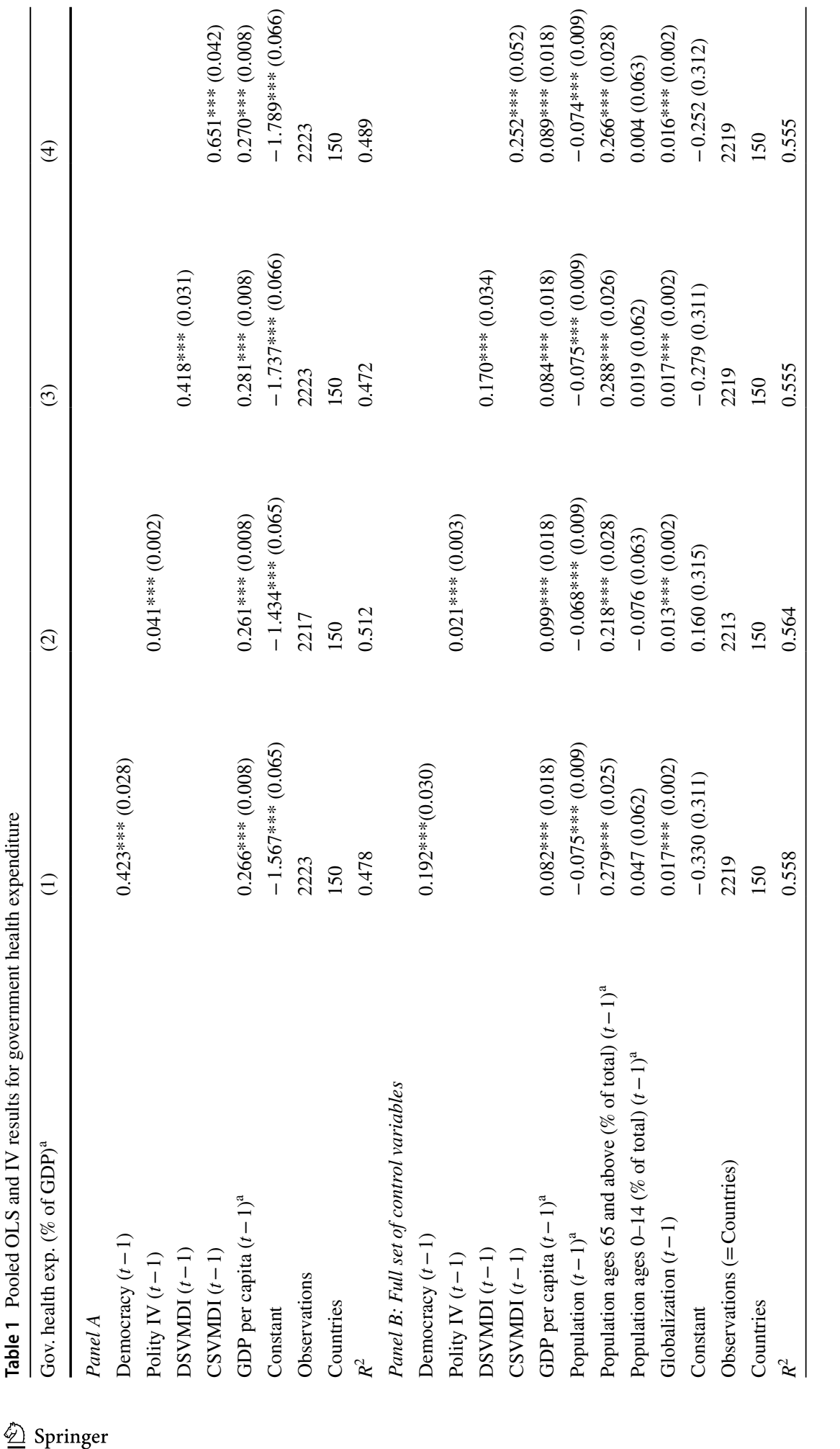




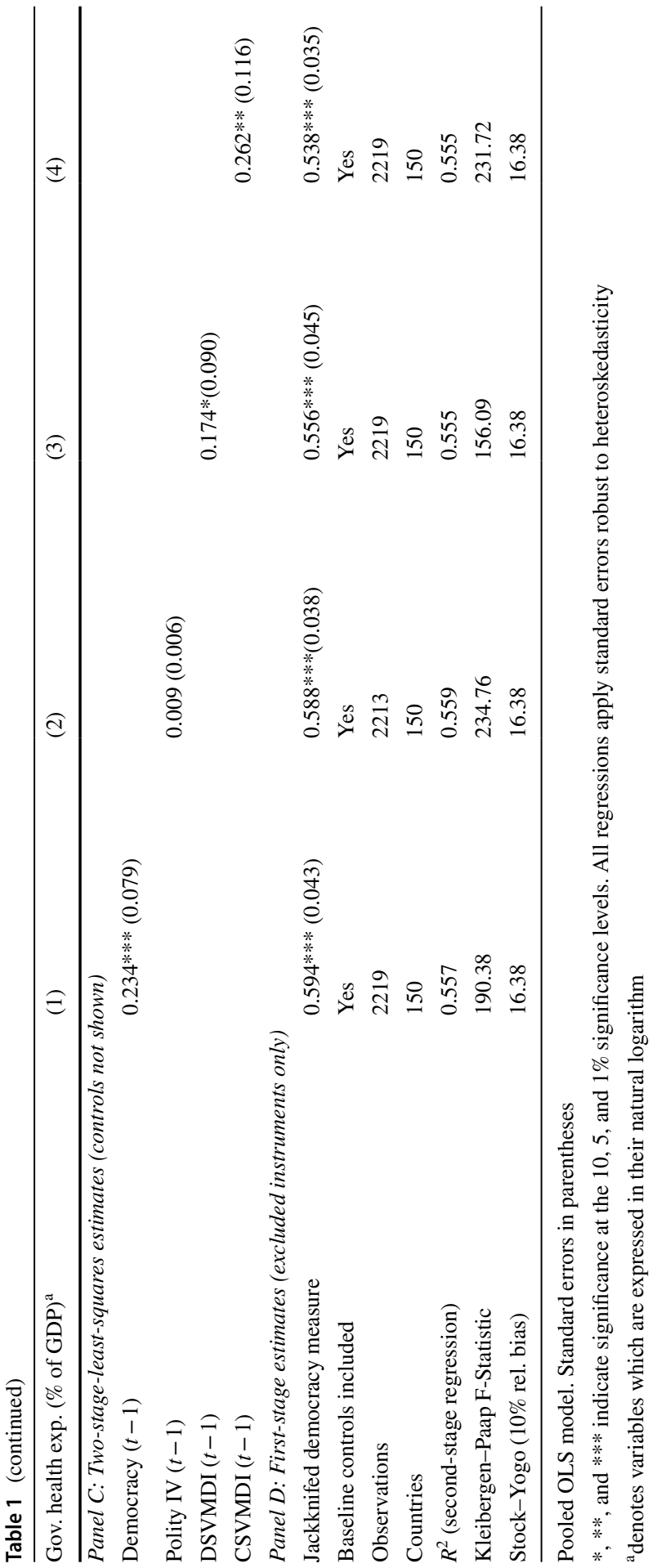




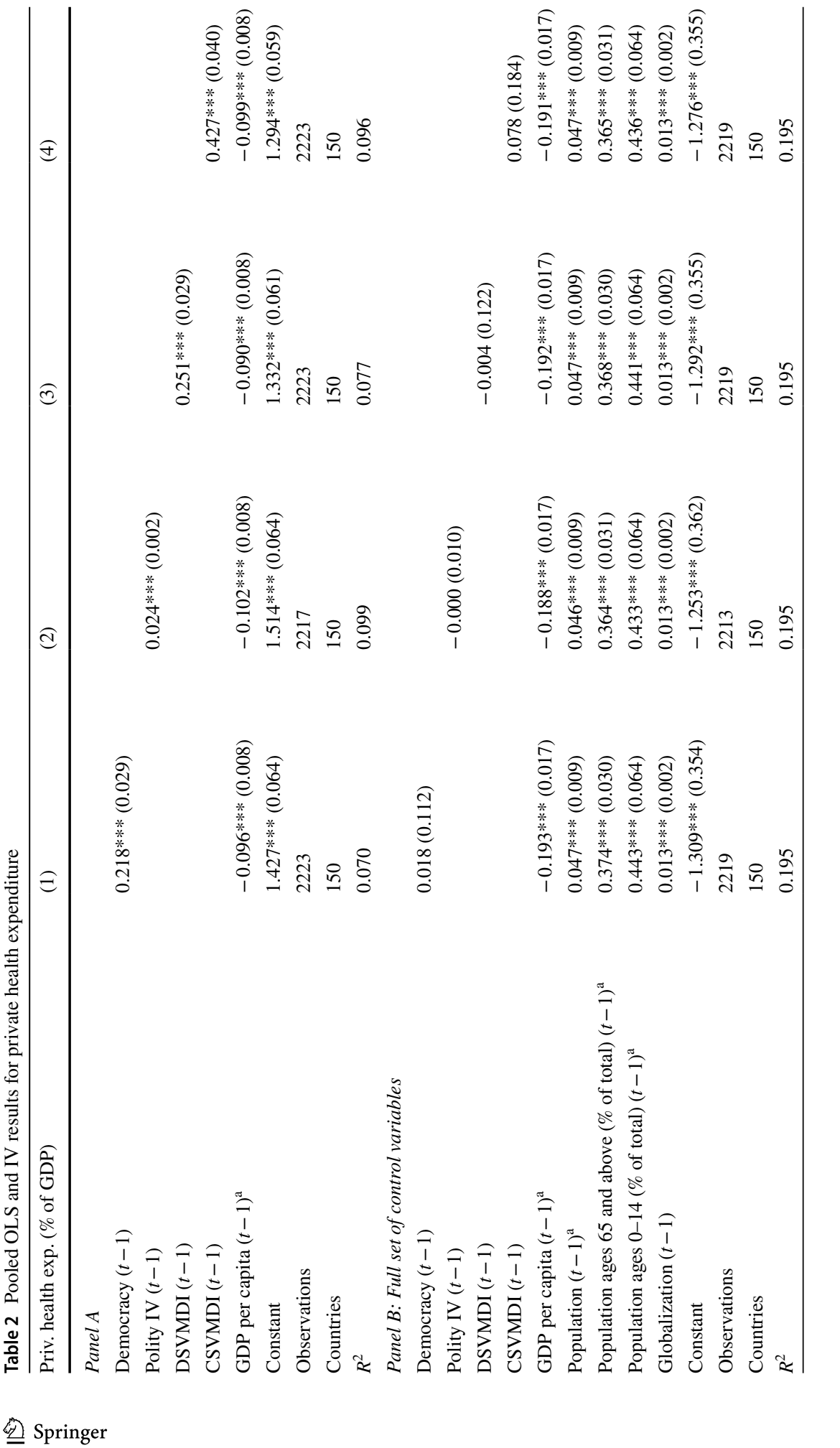




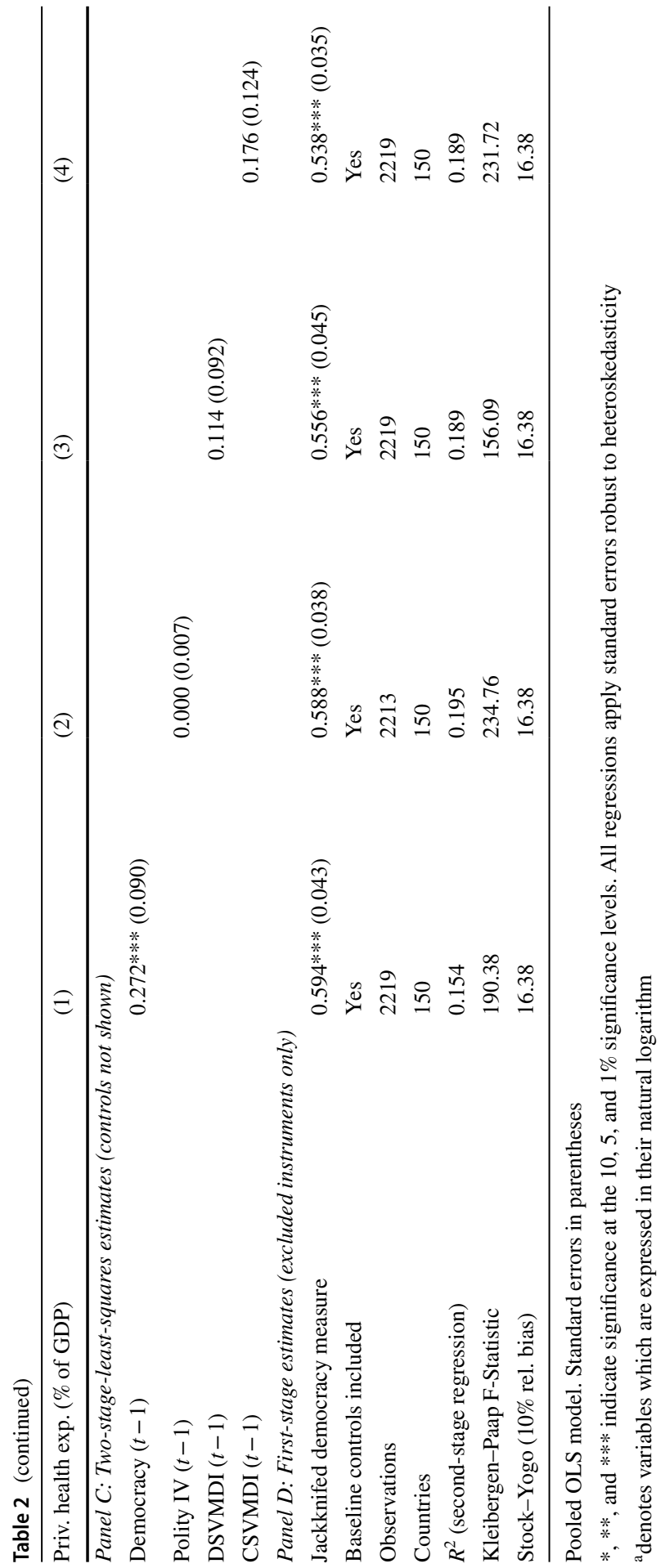


2018). ${ }^{13}$ The influence of democracies within the same region might, moreover, slightly initiate a democratization of political institutions in the home country which also gives rise to positive effects on government health expenditure far before the country is described as a pure democracy in our dichotomous democracy scores (see Sect. 5). OLS estimates for democracy-particularly the dichotomous ones-thus underestimate the favorable effects of the process of democratization and arising political institutions on government health expenditure which precede the final transition to a democracy.

The first-stage estimation results show a highly significant correlation between the jackknifed democracy measures and the democracy score of the country itselfevidence for the high relevance of the instrument. The $F$-statistics on the excluded instrument are all well above the $10 \%$-critical value suggested by Stock and Yogo (2005).

Pooled OLS and IV results in Table 2 suggest that democratic institutions do hardly affect private health expenditure. All democracy measures are positive and statistically significant at the 1\%-level in Panel A of Table 2, but drop in size and lack statistical significance once the full set of control variables is included in Panel B of Table 2. The finding is largely supported once democracy measures are instrumented in Panel C of Table 2. The instrumented Democracy variable by Bjørnskov and Rode (2019) turns out to be an exception and has a positive and significant effect on private health expenditure.

The empirical results for the control variables in Panel B of Table 1 reveal further patterns of health expenditure in democracies and autocracies: GDP per capita and old age population share are positive and statistically significant at the $1 \%$ level. The significant estimates for GDP and old age population are likely to capture higher government health expenditure (relative to GDP) for high-income countries and their aging societies. The positive coefficient of GDP per capita may show an income effect as previously implied by Fig. 2 because richer countries exhibit higher government health expenditure (relative to GDP). Population, however, is negatively related to government health expenditure (relative to GDP) and the coefficient for the young age population share lacks statistical significance. Different from the results for general government health expenditure (relative to GDP), GDP per capita is negatively and significantly related to private health expenditure (relative to GDP) (see Table 2, Panel B). Contrary to the income effect on government health expenditure, private health expenditure may thus be subject to a substitution effect as previously suggested by Fig. 3. Population and the old age population share are positively and significantly correlated with private health expenditure (relative to GDP). The $\mathrm{R}$-squared in both the OLS and the IV models is considerably lower when private health expenditure instead of government health expenditure is the dependent variable (see Tables 1 and 2). The share of variation explained by the model is thus higher for government than for private health expenditure as dependent variable.

\footnotetext{
13 That is, the IV estimates are 22\% larger than OLS estimates for the democracy measure (Democracy) by Bjørnskov and Rode (2019), and 2-4\% larger for the machine learning-based democracy measures (DSVMDI, CSVMDI) by Gründler and Krieger $(2016,2018)$.
} 


\section{Panel fixed effects strategy}

\subsection{Panel fixed effects model}

Given the rather short observation period from 2000 to 2015, variation in democracy within countries is rather low. It is, however, a worthwhile endeavor to estimate a panel fixed effects model and examine within-country effects of democracy for the countries which experienced regime transition during the period 2000 to 2015 (see Table 5 in Appendix):

$$
y_{\mathrm{it}}=\beta \text { Democracy }_{\mathrm{it}-1}+x_{\mathrm{it}-1} \delta+\alpha_{i}+\gamma_{t}+\varepsilon_{\mathrm{it}} \quad \text { with } t=2000, \ldots, 2015 .
$$

Time-invariant country fixed effects $\alpha_{i}$ account for country-specific unobserved characteristics and allow a within-interpretation of the estimated regression parameters. Year fixed effects $\gamma_{t}$ absorb common shocks to health expenditure during the observation period. The coefficient $\beta$ thus describes the within-country effect of democracy on government and private health expenditure. ${ }^{14}$ Error terms $\varepsilon_{\mathrm{it}}$ are clustered at the country level and robust to serial correlation and heteroskedasticity. ${ }^{15}$

The IV strategy applied in the cross-country OLS model is not feasible for the panel fixed effects model. First-stage regression results do not show that withincountry variation in the spatial democracy score is a relevant instrument for democracy in the period 2000-2015. The jackknifed democracy instrument by Acemoglu et al. (2019) follows the assumption that democracy in one country is influenced by democracy in countries of the same region. In a panel setup, which includes the period of the third wave of democratization as defined by Huntington (1991a, b), this relationship is reasonable to assume: the third wave of democracy reached different regions at different times and gave rise to democratizations within entire regions like Latin America and Eastern Europe. The countries in our sample which experienced regime transitions during the period 2000-2015 do not describe cohesive democratizations within a specific region and at a specific time. The IV strategy using an average democracy score of countries in the same geopolitical region can therefore not be applied to a panel fixed effects setup of our observation period.

\subsection{Panel fixed effects results}

Tables 3 and 4 show panel fixed effects results for the effect of democracy on general government and private health expenditure (relative to GDP). Different from the cross-country approach, the panel fixed effects model yields within-country estimates for the effect of democracy on government and private health expenditure and

\footnotetext{
14 The transition countries in our panel experienced regime transitions in both directions, i.e., from autocracy to democracy and from democracy to autocracy, or even experienced multiple transitions. We consider both for estimating the within-country effect of democracy.

15 According to the results of a Hausman test, which rejects the null hypothesis at all conventional significance levels, the fixed effects model is more appropriate compared to a random effects model in this empirical setup (not reported).
} 


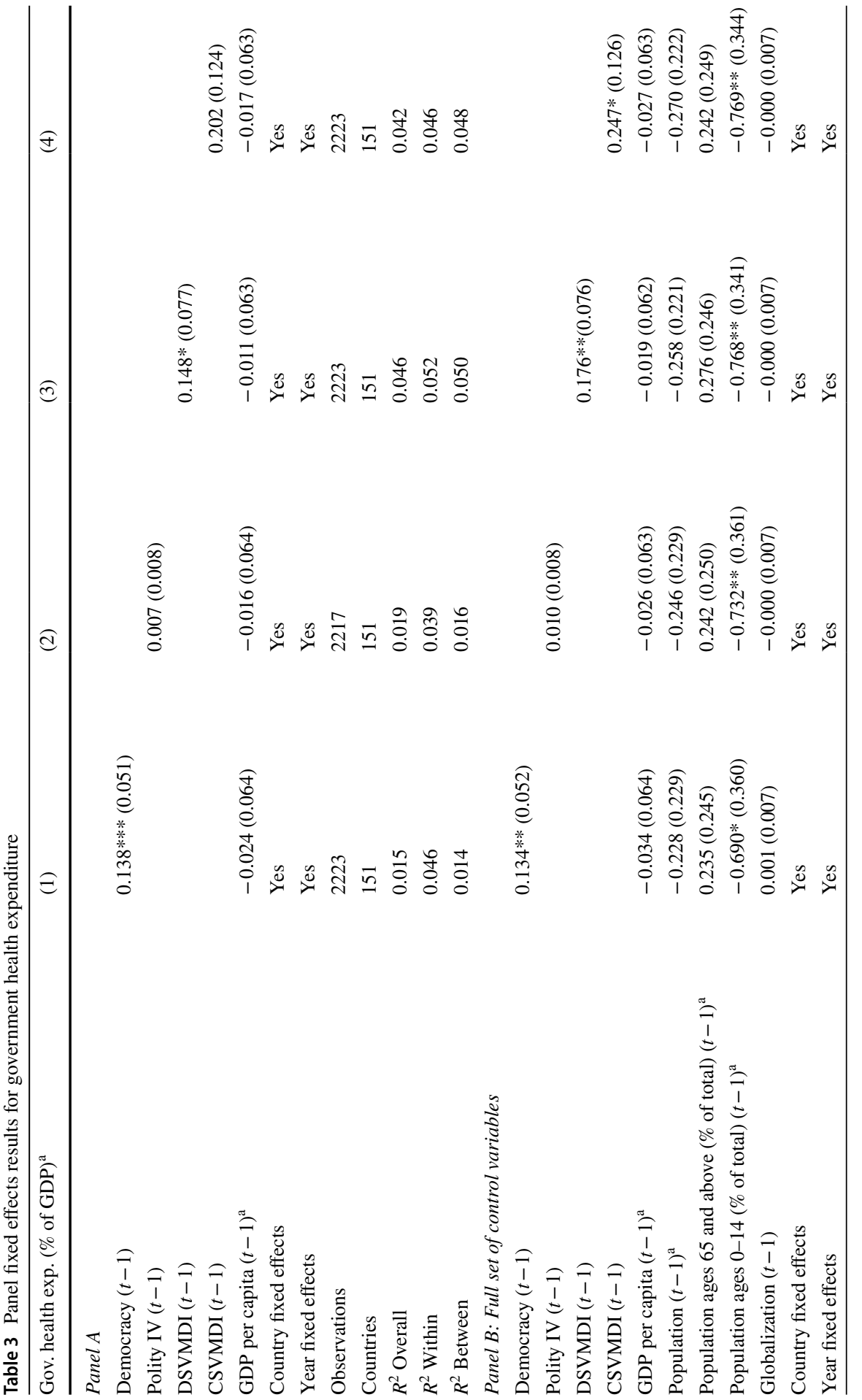




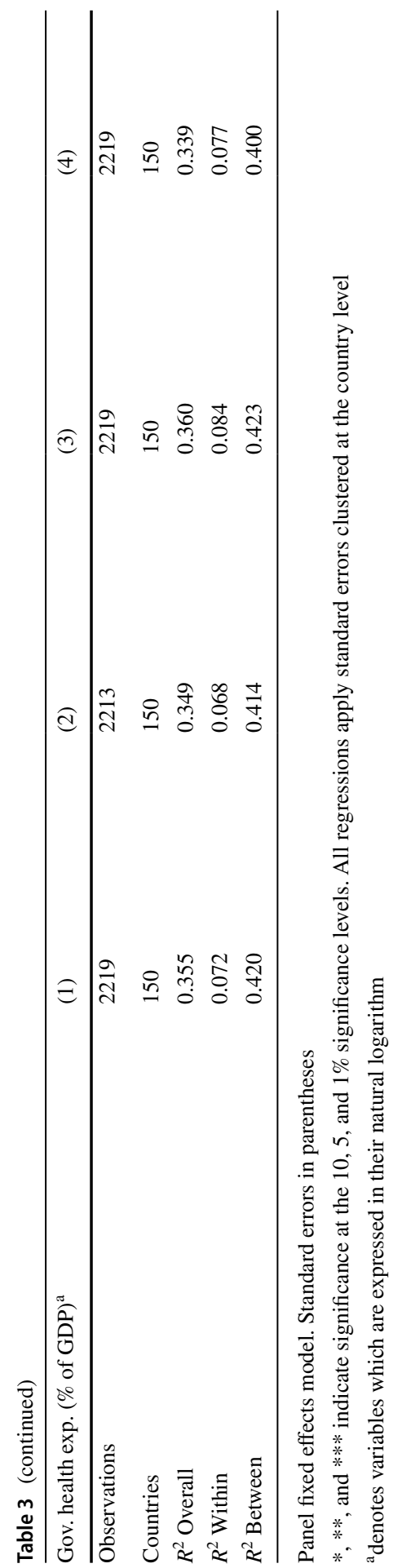




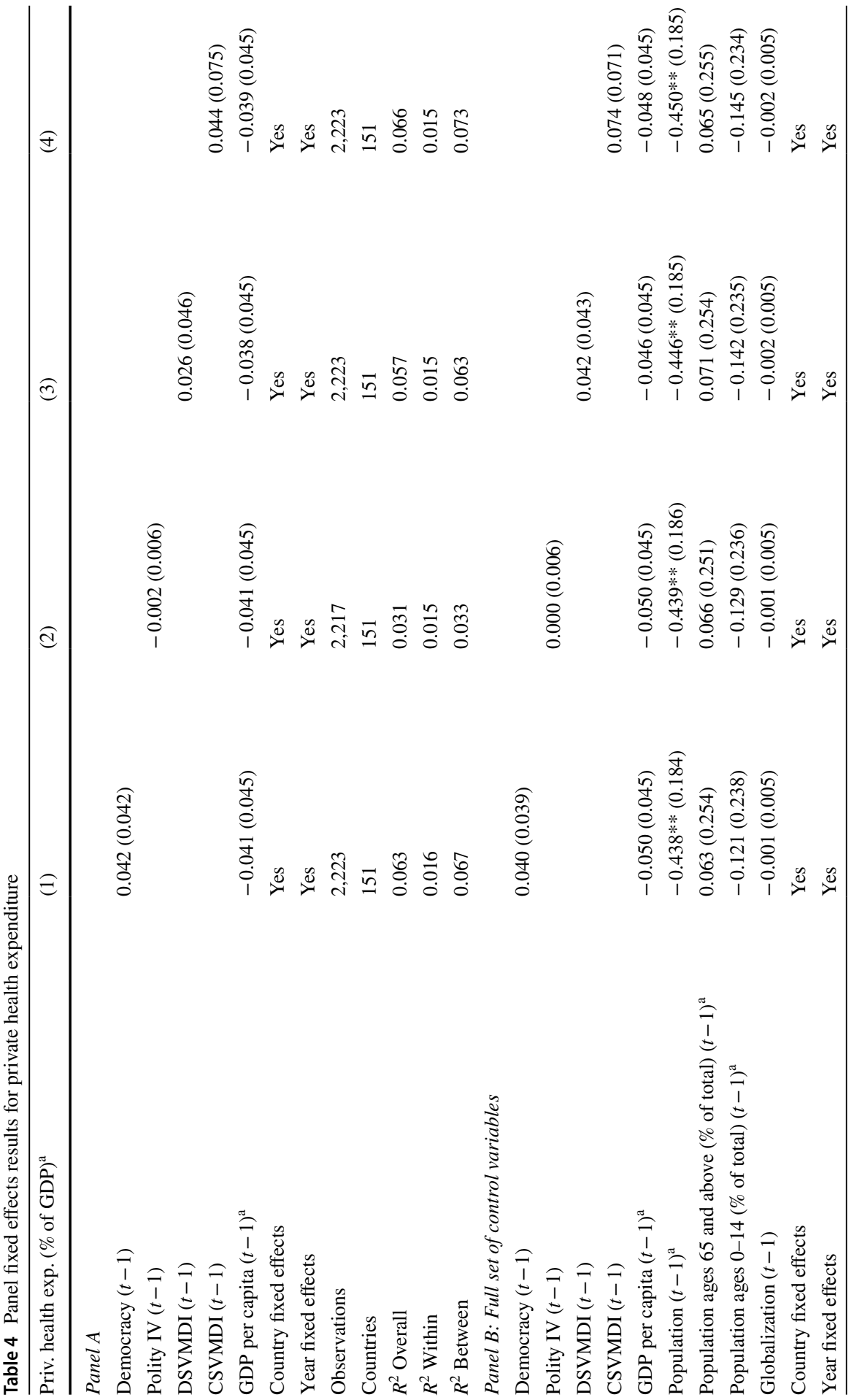




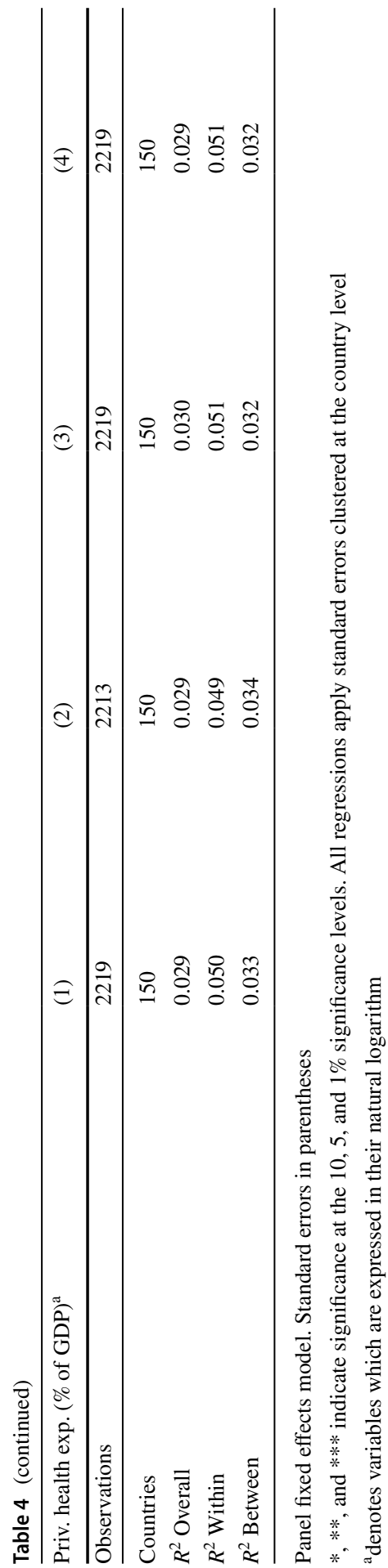


describes the transition effect of political regime changes within countries. Panel A of Tables 3 and 4 shows fixed effects results which are conditioned on GDP per capita only and Panel B of Tables 3 and 4 includes the full set of control variables as described by Eq. (5). ${ }^{16}$

The coefficient estimates of the dichotomous democracy measures Democracy by Bjørnskov and Rode (2019) and the DSVMDI on general government health expenditure in Table 3 are statistically significant at the $1 \%$ and $10 \%$ level in Panel A of Table 3, while the democracy measures of Polity IV and CSVMDI do not turn out to be statistically significant. After including the full set of control variables in Panel B, both dichotomous democracy measures are statistically significant at the $5 \%$ level and indicate that countries increase government health expenditure (relative to GDP) by $14 \%$ and $19 \%$ according to columns (1) and (3). The continuous CSVMDI democracy measure also turns out to be statistically significant at the $10 \%$ level and suggests that government health expenditure (relative to GDP) increases by $28 \%$ for a hypothetical transition to democracy from 0 to 1 (see Table 3 , Panel $\mathrm{B}$, column 4). The results indicate that the difference in government health expenditure becomes visible in a rather short time period after transition between political regimes. The size of the effect is smaller compared to the pooled OLS results because it only accounts for countries which experienced a transition during the observation period and thus only covers short- and medium-term budgetary adjustments after regime transitions. The low within-R-squared in Panel B compared to the rather high between-R-squared indicates that the variation in the data predominantly applies across countries rather than within countries and further explains the reduced significance of the within estimates compared to the between estimates for democracy.

The panel fixed effects results in Table 4 show that democracy does not turn out to be statistically significant when private health expenditure (relative to GDP) is the dependent variable. Democratic transitions thus do not seem to influence out-ofpocket health expenditure in a significant manner.

The results for our control variables in our panel fixed effects model (Tables 3 and 4, Panel B) show that the young age population share is negatively related to government health expenditure (relative to GDP), whereas population is negatively related to private health expenditure (relative to GDP).

\section{Event study strategy}

\subsection{Event study model}

We use the time series variation of regime transitions in an event study design to examine the dynamics of the effect of regime transitions on health expenditures. The event study is based on a panel difference-in-difference approach and shows whether

\footnotetext{
16 The number of observations is slightly smaller in column (2) because of missing values for the Polity IV index.
} 
health expenditures evolve differently in years before and after regime transition. Moreover, the event study shows whether transition effects are persistent in the years thereafter.

Countries experience regime transitions at different times. The flexible design of our event study model allows us to employ all regime transitions in a parallel structure, irrespective of when they have experienced a regime transition in the period 2000-2015. Event studies employ year-specific dummy variables for years before and after regime transition for countries which experienced transitions from autocracies to democracies or vice versa. The flexible event study model augments the panel fixed effects model by year-specific dummy variables and looks as follows:

$$
y_{t}=\sum_{T=t-8}^{T=t+8} \beta_{T}\left(\text { Regime Transition }_{i, t}^{T}\right)+x_{i t} \delta+\alpha_{i}+\gamma_{t}+\varepsilon_{t} \quad \text { with } t=2000, \ldots, 2015 .
$$

Equation (6) estimates the impact of regime transitions for individual years before and after transition. We estimate both, the effect of transitions from autocracy to democracy as well as the effect of transitions from democracy to autocracy separately by employing Eq. (6). The event study design considers regime transitions as treatments. We therefore employ dichotomous democracy measures to classify when a country experienced a regime transition. ${ }^{17}$ We use the dichotomous democracy measure DSMVDI by Gründler and Krieger $(2016,2018)$ as main indicator to classify countries as a democracy or autocracy in the event study design. Compared to the dichotomous measure Democracy by Bjørnskov and Rode (2019), the DSMVDI captures more regime transitions (see Table 5 in Appendix), and provides less biased OLS estimates (see Sect. 3.2). ${ }^{18}$

In Eq. (6), the column vector Regime Transition ${ }_{i, t}^{T}$ describes whether country $i$ is under democratic or autocratic rule in year $t$. When we examine the effect of transitions toward democracies the vector takes the value of one if a country is classified as a democracy; when we examine transitions from democratic rule to autocracies, it takes the values of one for years if the country is classified as an autocracy and zero for democracies. Regime transitions take place in the year $t$, and $T$ describes years $t$ prior and after the regime transition. $T$ ranges from $t-8$ (and years before), to $t+8$ (and years after). The year prior to the regime transition, $t-1$, serves as the reference year. The coefficients $\beta_{T}$ thus estimate the effect from $t-8$ years before transition to $t+8$ years after transition. We include all control variables in vector $\boldsymbol{x}_{i t}$ as described in our baseline model; $\gamma_{t}$ and $\alpha_{i}$ capture year and country fixed effects. Standard errors $\varepsilon_{t}$ are clustered at the country level and robust to serial correlation and heteroskedasticity.

\footnotetext{
17 The event study applies the dichotomous democracy measures because-different from CSVMDI and the Polity IV index - a treatment-like effect can be estimated with a dichotomous democracy measure only.

18 However, we have repeated the approach by using the Democracy score by Bjørnskov and Rode (2019). Inferences do not change. Results available upon request.
} 


\subsection{Event study results}

Figures 4 and 5 show the coefficient estimates of the event study model following Eq. (6) by using the dichotomous democracy measure DSVMDI by Gründler and Krieger $(2016,2018) .{ }^{19}$ The event study figures describe how health expenditure evolves in the years before and after the regime transition. Each dot in the figure presents a point estimate, the vertical lines are $90 \%$ confidence intervals. Figure 4 illustrates the effect of the transition from an autocratic system to democratic rule, whereas Fig. 5 shows how the effect on health expenditure evolves around the transition from a democratic regime to an autocracy. In both figures, panel (a) refers to estimates including the full country sample, and panel (b) presents results of the sample excluding permanent democracies from the regression sample.

The event study results in Fig. 4 confirm that a transition to democracy gives rise to significantly higher government health expenditure. The effect on government health expenditure is positive and statistically significant in the transition year $(T=0)$ and up to seven years after the regime transition. The point estimates remain positive in the following years indicating that the positive effect of democratization on government health expenditure is persistent. It lacks, however, statistical significance in some later years, since the number of observations for transition countries is reduced for later years due to the rather short observation period, and thus gives rise to larger standard errors. The reference for the estimates is one year before transition $(t-1)$. The estimates for years prior to the reference year indicate that government health expenditure already increased to some extent before the dichotomous democracy measure classifies the political system as democracy. An arguable reason is that the process of democratization already started in some transition countries before the threshold year (see arguments why IV results are larger than pooled OLS estimates in Sect. 3). The positive effect of the democratic transition on government health expenditure is therefore likely to be underestimated when we compare the years after transition with the reference year.

The positive effect of democratic rule on government health expenditure is also confirmed in Fig. 5. The figure shows how estimates evolve before and after a regime transition from a democracy to an autocratic system. The transition to an autocratic system has a negative and statistically significant effect on government health expenditure three years after transition and up to seven years later. The negative effect remains persistent according to the full sample in panel (a). By contrast, democratic years three years before transition to autocracy and earlier show a positive and significant effect of democratic rule on government health expenditure. Again, the decline in government health expenditure already started two years before the dichotomous democracy measure classifies the country as an autocracy. This refers to a process of decline in democratic institutions in some transition countries which started before transition and proceeded in the years thereafter. This event study pattern again suggests that the point estimates underestimate the positive

19 The numerical results are presented in Tables 8-11 in Online Appendix II. 
effect of democratic (and the negative effect of autocratic) transition on government health expenditure.

By contrast, Fig. 4 does not show that private health expenditure evolves differently before and after democratic transition. The figure shows only one significant point estimate in year $t+3$ after transition, but the effects are not persistent. However, Fig. 5 shows that private health expenditures follow a U-shape around transitions to autocracy. Private health expenditures are first significantly larger in years prior to the autocratic transition. Then, private health expenditures drop in the years around the transition to an autocratic regime, but finally increase five years after the regime transition. This suggests that previous findings of a positive relationship between democratic rule and private health expenditure are mainly driven by the drop in "out-of-pocket" health expenditures in the initial years of autocratic rule. Overall, event study results do not suggest that regime transitions have persistent effects on private health expenditures, while effects of regime transitions on government health expenditures are significant and persistent.

\section{Robustness tests}

We test the robustness of our empirical results in several ways. First, we estimate the empirical models for a sample excluding high-income countries to confirm that the empirical results are not driven by the pronounced differences in government health expenditure between democracies and autocracies in the group of high-income countries (see Fig. 1). The pooled OLS, IV, and panel fixed effects estimation results in Tables 12-15 in Online Appendix II show that the positive effect of democratization on government health expenditure hardly changes once we exclude high-income countries. The results support previous findings of Avelino et al. (2005) and Profeta et al. (2013). Both report positive coefficient estimates in samples of developing and low-income countries. However, their results are based on rather smaller samples and observations and do not show significant (linear) effects of regime transitions on health expenditure within countries. Avelino et al. (2005) and Profeta et al. (2013) both do not report estimates for the relationship between democracy and private health expenditure. Our pooled OLS and IV estimation results suggest that regime transitions toward stronger democratic institutions decrease private health expenditures once we exclude high-income countries. The findings may indicate a substitution effect between government health expenditure and private health expenditure in developing and low-income countries.

Second, the estimation results refer to a pooled OLS and IV regression for the years 2000 to 2015. To rule out that our estimation results depend on the pooled sample selection, Figures 6-9 in Online Appendix II illustrate OLS and IV coefficient cross-country estimates and their $90 \%$ confidence intervals for the four democracy measures in all years from 2000 to 2015. We estimate Eqs. (1) and (4) for each single year between 2000 and 2015 separately. The findings confirm that democracy has a positive effect on general government health expenditure (relative to GDP) for all democracy measures. The results confirm that our inferences from the pooled approach are also valid for most of the individual years during the observation 


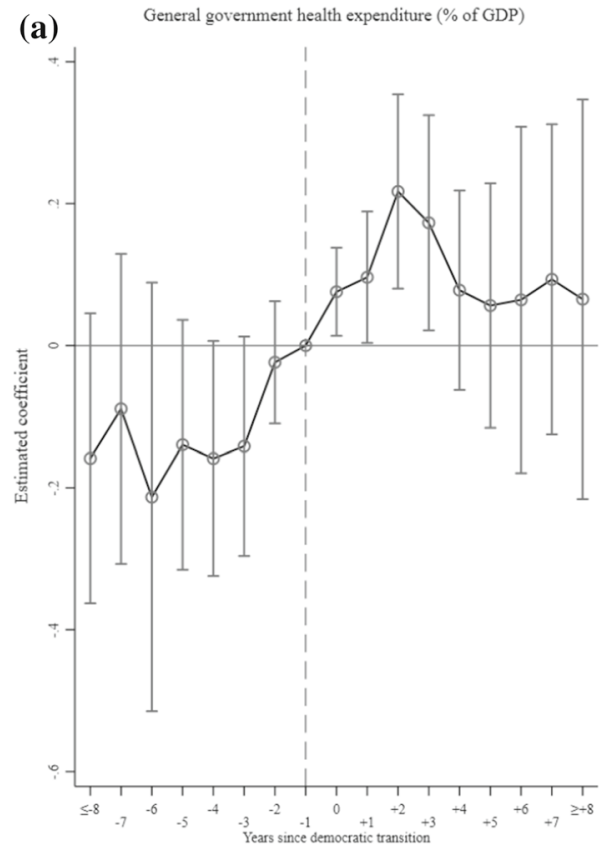

Private health expenditure ( $\%$ of GDP)

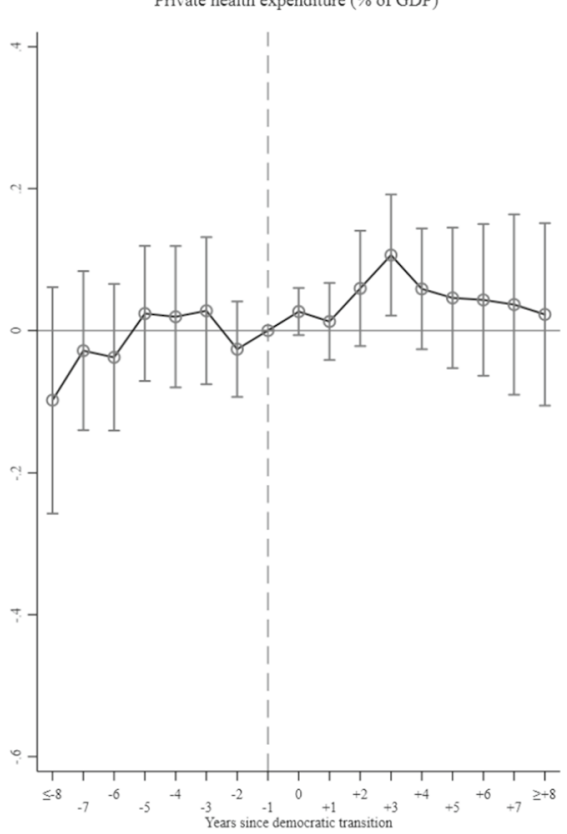

(b)

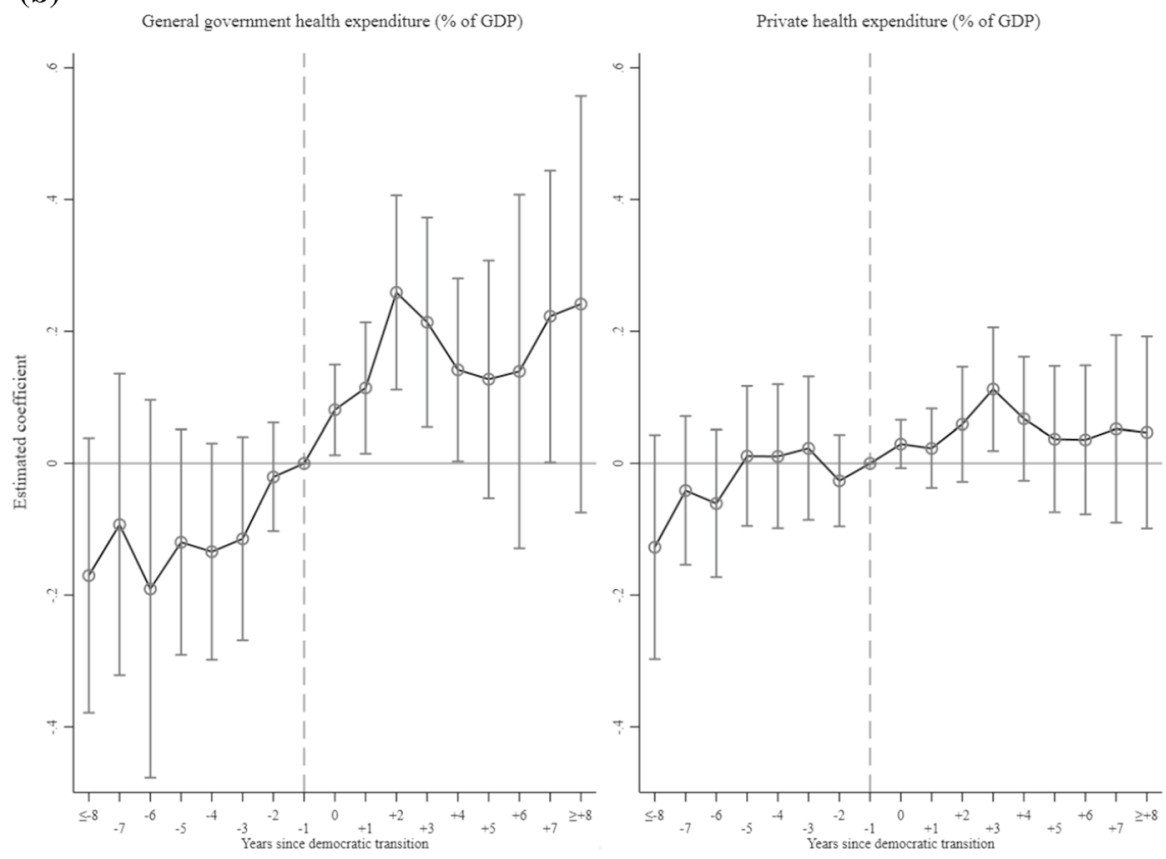

Fig. 4 Event Study-Democratic Transition. Event study model using the dichotomous DSMVDI democracy measure. Panel model includes country and year fixed effects, baseline controls, and clustered standard errors at the country level. Panel (a) includes all countries, panel (b) excludes permanent democracies. Figure refers to Tables 8 and 9, columns (4) and (6) in Online Appendix II 

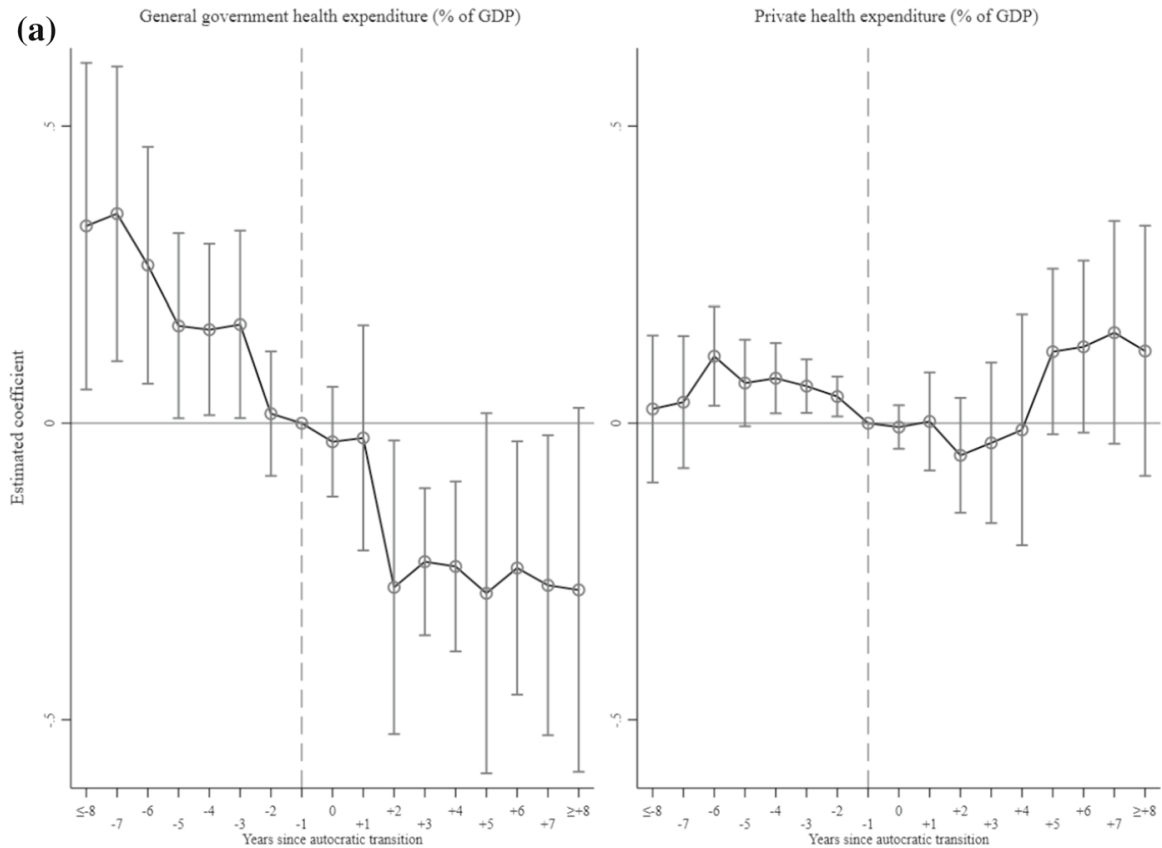

(b)
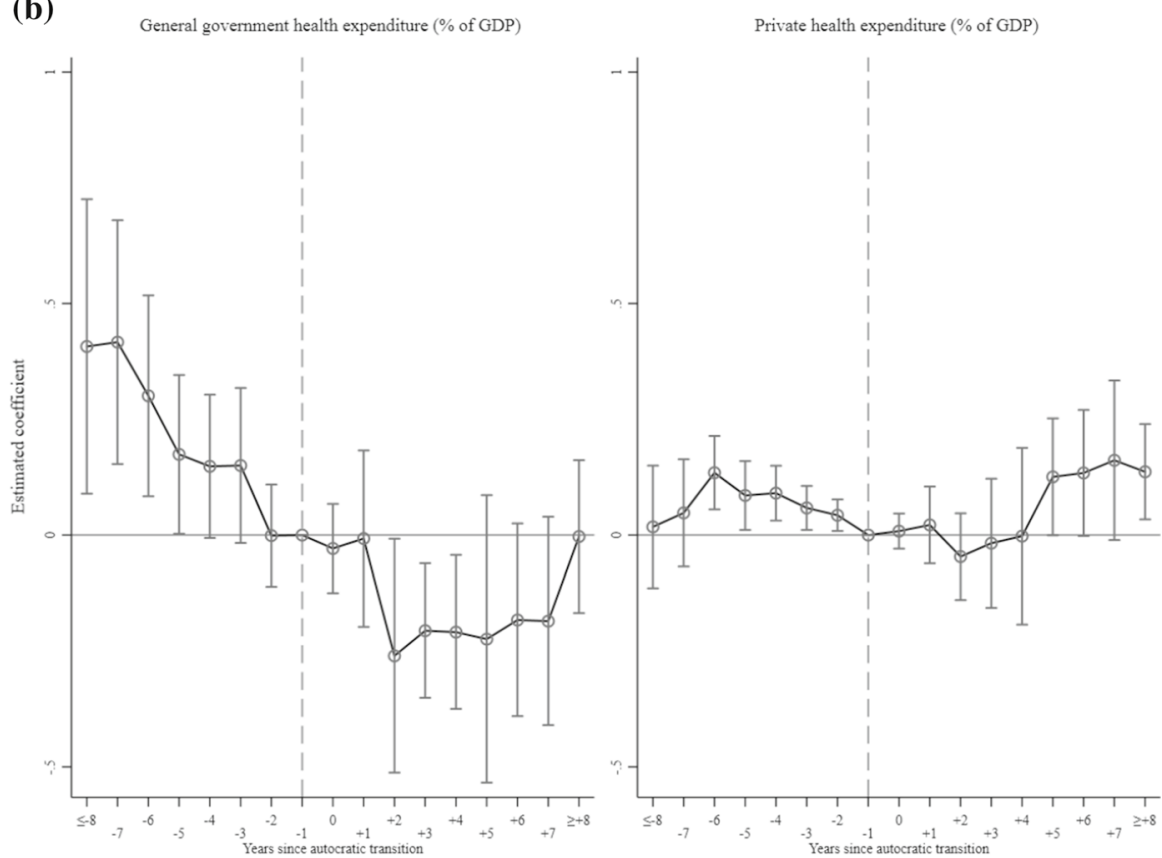

Fig. 5 Event Study-Autocratic Transition. Event study model using the dichotomous DSMVDI democracy measure. Panel model includes country and year fixed effects, baseline controls, and clustered standard errors at the country level. Panel (a) includes all countries, panel (b) excludes permanent democracies. Figure refers to Tables 10 and 11, columns (4) and (6) in Online Appendix II 
period. OLS and IV estimates for the relationship between democracy and government health expenditure are positive with quite homogeneous point estimates across all years. They, however, lack statistical significance in some years, likely because of the small size of observations in single years. Naturally, the less precise IV results more often lack significance than OLS estimates due to larger standard errors. Both OLS and IV estimates do not suggest that democracy has a positive effect on private health expenditure (relative to GDP), estimating the cross-country model for all democracy measures across all single years notwithstanding (see Figures 6-9 in Online Appendix II).

Third, the effect of democracy on health expenditure may well depend on the age of democracy (see Besley and Kudamatsu 2006). Our pooled OLS and panel fixed effects baseline results suggest that the quality of political institutions may differ between established democracies and countries which recently experienced democratic transition. We therefore include a dummy variable for established democracies in the pooled OLS and IV models according to the two dichotomous democracy measures. The dummy takes the value of one if our dichotomous democracy measures (Democracy, DSVMDI) classify a country as democracy in all years of the sample period. The findings in the pooled OLS and IV analysis show that established democracies indeed spend more on government health expenditure (relative to GDP).$^{20}$ However, democracy also turns out to be positive in the remaining sample of countries which corroborates the findings of the panel fixed effects and event study models (Figures 10 and 11 in Online Appendix II). When we control for established democracies, democratization seems to increase private health expenditure. This is, however, probably due to the U-shape effect during autocratic transitions as discussed in the event study Sect. 5.

Finally, we include further control variables in our empirical models: population share in geographical tropics, ${ }^{21}$ urban population share, Gini index of market income inequality, and military expenditure (relative to GDP). ${ }^{22}$ The population in geographical tropics has an increased likelihood of exposure to severe diseases and epidemics (e.g., the spread of malaria or the Ebola epidemic in West Africa in the mid-2010s), which might influence health expenditure. ${ }^{23}$ We include urban population share as higher population density might be related to the spread of diseases and epidemics, as well as to the diffusion of political ideas and the spread

\footnotetext{
${ }^{20}$ Estimation results for additional control variables available upon request.

21 We cannot apply the population share in geographical tropics in our panel data models because the data are not available over time.

22 Data on population density are taken from the World Bank. Data on income inequality (before taxes and transfers) are Gini measures from the Standardized World Income Inequality Database (SWIID) (Solt 2016). Data on military expenditure are provided by the Stockholm International Peace Research Institute (SIPRI).

23 The population share in geographical tropics is provided by the Country-Geography-Dataset of the College of Urban and Public Affairs at the Portland State University (Gallup et al. 1999). Data for the population share in geographical tropics are as of 1995 and available across countries but not over time. The population share in geographical tropics is not used in its natural logarithm because of the high number of zero values for many countries. The variable is not available for all countries and therefore can only be tested for 139 of the 151 countries in the sample.
} 
of potential political protest of the electorate (e.g., protest movements). In addition, income inequality may well increase the demand of the electorate for higher taxation, redistribution, and social spending such as government health expenditures (see Meltzer and Richard 1981; Gründler and Köllner 2017). Following the discussion of the "butter vs. guns" trade-off, the relative share of military expenditures, moreover, might be negatively related to social spending (see Bove et al. 2017). Inferences for the effect of political institutions on health expenditure do not change once we include additional controls which justifies the selection of our baseline controls. Point estimates are reported in Figures 10 and 11 in Online Appendix II. ${ }^{24}$ In a last step, we employ error terms $\varepsilon$ clustered at the country level and robust to serial correlation and heteroskedasticity in the pooled OLS and IV models. Point estimates and inferences do not change, whereas standard errors increase and IV estimates lack statistical significance (see Figures 10 and 11 in Online Appendix II).

\section{Conclusion}

We examined the effect of political institutions on health expenditure. Our empirical approach included some novel contributions: first, we employed a large balanced panel of 151 developing and developed countries during the period 2000 to 2015 and estimated cross-country and panel data models which allow us to estimate both between- and within-country effects of democracy. Second, we distinguished between the effect of democracy on both general government health expenditure and private ("out-of-pocket") health expenditure to examine whether democratic regimes differently affect government and private health expenditure. Third, we used four measures of democracy to account for differences in the quantification of democracy. Fourth, we used instrumental variable approaches to deal with endogeneity problems. We exploited the regional diffusion of political institutions as an instrumental variable for democracy in our cross-country analysis.

The cross-country estimation results confirm previous cross section studies (Besley and Kudamatsu 2006; Gregorio and Gregorio 2013; Profeta et al. 2013) suggesting that democracy has a positive and statistically significant effect on government health expenditure (relative to GDP). Our findings suggest that according to dichotomous democracy measures, democratic governments spend about 20-30\% more on health relative to GDP than their autocratic counterparts. While previous studies do not find significant effects in panel fixed effect approaches (Avelino et al 2005; Profeta et al. 2013), our results indicate a positive within-country effect of democratization on government health expenditure (relative to GDP), which become visible within a rather short time period after regime transition. Our findings suggest a positive

\footnotetext{
${ }^{24}$ The point estimate of the democracy measures slightly decreases once including Gini market inequality. Including Gini market, however, decreases the number of observations in the estimation model. Once including the tropical population share and the military expenditure (as \% of GDP) as additional control variables, 2SLS coefficients of the democracy effect on both, government and private health expenditure, increase in size.
} 
within-country effect of democratization of about 10-20\% according to dichotomous democracy measures. Event study results corroborate that regime transitions from autocracies to democracies and vice versa give rise to significant changes in government health expenditure within a short time period after transition. Regime transitions, however, do not turn out to significantly influence private health expenditure.

The short observation period from 2000 to 2015 includes only little variation in democracy within countries and limits the time window in which budget adjustments after regime changes can be observed. Once longer time series are available for government and private health expenditure, future research should further investigate within-country effects of regime transition on health expenditure.

Higher government health expenditure may well give rise to health infrastructure improvements such as better access to physicians and hospitals. Empirical evidence has shown that democracies-compared to autocratic regimes at the same stage of economic development - are indeed associated with a higher quality of the healthcare sector, improved sanitation and clean water supply, higher immunization rates and coverage of medical treatment of diseases, as well as improvements in health indicators such as life expectancy and child or infant mortality rates (e.g., Lake and Baum 2001; Besley and Kudamatsu 2006; Deacon 2009; Klomp and de Haan 2009; Justesen 2012; Kudamatsu 2012; Welander et al. 2015). We conclude that governments in democracies care more for their people and increase public health by decreasing inequalities in the access to costly health services.

\section{Appendix}

See Tables 5, 6 and 7. 
Table 5 List of Countries

\begin{tabular}{|c|c|c|c|c|c|}
\hline \multirow[t]{2}{*}{ ID } & \multirow[t]{2}{*}{ Country } & \multicolumn{4}{|c|}{ Variation in democracy measures } \\
\hline & & Democracy & Polity IV & DSVMDI & CSVMDI \\
\hline 1 & Afghanistan & No & Yes & No & Yes \\
\hline 2 & Albania & No & Yes & No & Yes \\
\hline 3 & Algeria & No & Yes & Yes & Yes \\
\hline 4 & Angola & No & Yes & No & Yes \\
\hline 5 & Argentina & No & No & No & Yes \\
\hline 6 & Armenia & No & No & No & Yes \\
\hline 7 & Australia & No & No & No & Yes \\
\hline 8 & Austria & No & No & No & Yes \\
\hline 9 & Azerbaijan & No & No & No & Yes \\
\hline 10 & Bahrain & No & Yes & No & Yes \\
\hline 11 & Bangladesh & Yes & Yes & Yes & Yes \\
\hline 12 & Belarus & No & No & Yes & Yes \\
\hline 13 & Belgium & No & Yes & No & Yes \\
\hline 14 & Benin & No & Yes & No & Yes \\
\hline 15 & Bhutan & Yes & Yes & Yes & Yes \\
\hline 16 & Bolivia & No & Yes & No & Yes \\
\hline 17 & Botswana & No & No & No & Yes \\
\hline 18 & Brazil & No & No & No & Yes \\
\hline 19 & Bulgaria & No & Yes & No & Yes \\
\hline 20 & Burkina Faso & No & Yes & Yes & Yes \\
\hline 21 & Burundi & Yes & Yes & Yes & Yes \\
\hline 22 & Cambodia & No & No & No & Yes \\
\hline 23 & Cameroon & No & No & No & Yes \\
\hline 24 & Canada & No & No & No & Yes \\
\hline 25 & Central African Republic & Yes & Yes & Yes & Yes \\
\hline 26 & Chad & No & No & Yes & Yes \\
\hline 27 & Chile & No & Yes & No & Yes \\
\hline 28 & Colombia & No & No & No & Yes \\
\hline 29 & Comoros & Yes & Yes & Yes & Yes \\
\hline 30 & Congo & No & Yes & No & Yes \\
\hline 31 & Congo, Dem. Rep & No & Yes & Yes & Yes \\
\hline 32 & Costa Rica & No & No & No & Yes \\
\hline 33 & Croatia & No & Yes & No & Yes \\
\hline 34 & Cyprus & No & No & No & Yes \\
\hline 35 & Denmark & No & No & No & Yes \\
\hline 36 & Djibouti & No & Yes & No & Yes \\
\hline 37 & Dominican Republic & No & No & No & Yes \\
\hline 38 & Ecuador & Yes & Yes & Yes & Yes \\
\hline 39 & Egypt & No & Yes & Yes & Yes \\
\hline 40 & El Salvador & No & Yes & No & Yes \\
\hline 41 & Equatorial Guinea & No & No & No & Yes \\
\hline
\end{tabular}


Table 5 (continued)

\begin{tabular}{|c|c|c|c|c|c|}
\hline \multirow[t]{2}{*}{ ID } & \multirow[t]{2}{*}{ Country } & \multicolumn{4}{|c|}{ Variation in democracy measures } \\
\hline & & Democracy & Polity IV & DSVMDI & CSVMDI \\
\hline 42 & Eritrea & No & Yes & No & Yes \\
\hline 43 & Estonia & No & No & No & Yes \\
\hline 44 & Ethiopia & No & Yes & Yes & Yes \\
\hline 45 & Fiji & Yes & Yes & Yes & Yes \\
\hline 46 & Finland & No & No & No & Yes \\
\hline 47 & France & No & No & No & Yes \\
\hline 48 & Gabon & No & Yes & Yes & Yes \\
\hline 49 & Georgia & Yes & Yes & Yes & Yes \\
\hline 50 & Germany & No & No & No & Yes \\
\hline 51 & Ghana & No & Yes & No & Yes \\
\hline 52 & Greece & No & No & No & Yes \\
\hline 53 & Guatemala & No & No & No & Yes \\
\hline 54 & Guinea & Yes & Yes & Yes & Yes \\
\hline 55 & Guinea-Bissau & Yes & Yes & Yes & Yes \\
\hline 56 & Guyana & Yes & No & No & Yes \\
\hline 57 & Haiti & No & Yes & Yes & Yes \\
\hline 58 & Honduras & No & No & Yes & Yes \\
\hline 59 & Hungary & No & No & No & Yes \\
\hline 60 & India & No & No & No & Yes \\
\hline 61 & Indonesia & Yes & Yes & No & Yes \\
\hline 62 & Iran & No & Yes & Yes & Yes \\
\hline 63 & Iraq & No & Yes & No & Yes \\
\hline 64 & Ireland & No & No & No & Yes \\
\hline 65 & Israel & No & No & No & Yes \\
\hline 66 & Italy & No & No & No & Yes \\
\hline 67 & Jamaica & No & No & No & Yes \\
\hline 68 & Japan & No & No & No & Yes \\
\hline 69 & Jordan & No & Yes & No & Yes \\
\hline 70 & Kazakhstan & No & Yes & Yes & Yes \\
\hline 71 & Kenya & No & Yes & No & Yes \\
\hline 72 & Kuwait & No & No & No & Yes \\
\hline 73 & Kyrgyzstan & Yes & Yes & Yes & Yes \\
\hline 74 & Laos & No & No & No & Yes \\
\hline 75 & Latvia & No & No & No & Yes \\
\hline 76 & Lebanon & No & Yes & Yes & Yes \\
\hline 77 & Lesotho & Yes & Yes & No & Yes \\
\hline 78 & Liberia & Yes & Yes & Yes & Yes \\
\hline 79 & Libya & No & No & No & No \\
\hline 80 & Lithuania & No & No & No & Yes \\
\hline 81 & Luxembourg & No & No & No & Yes \\
\hline 82 & Macedonia & No & Yes & No & Yes \\
\hline
\end{tabular}


Table 5 (continued)

\begin{tabular}{|c|c|c|c|c|c|}
\hline \multirow[t]{2}{*}{ ID } & \multirow[t]{2}{*}{ Country } & \multicolumn{4}{|c|}{ Variation in democracy measures } \\
\hline & & Democracy & Polity IV & DSVMDI & CSVMDI \\
\hline 83 & Madagascar & Yes & Yes & Yes & Yes \\
\hline 84 & Malawi & No & Yes & No & Yes \\
\hline 85 & Malaysia & Yes & Yes & No & Yes \\
\hline 86 & Mali & Yes & Yes & Yes & Yes \\
\hline 87 & Mauritania & Yes & Yes & Yes & Yes \\
\hline 88 & Mauritius & No & No & No & Yes \\
\hline 89 & Mexico & No & No & No & Yes \\
\hline 90 & Moldova & No & Yes & No & Yes \\
\hline 91 & Mongolia & No & No & No & Yes \\
\hline 92 & Montenegro & No & Yes & No & Yes \\
\hline 93 & Morocco & No & Yes & No & Yes \\
\hline 94 & Mozambique & No & No & Yes & Yes \\
\hline 95 & Myanmar & No & Yes & Yes & Yes \\
\hline 96 & Namibia & No & No & No & Yes \\
\hline 97 & Nepal & Yes & Yes & Yes & Yes \\
\hline 98 & Netherlands & No & No & No & Yes \\
\hline 99 & New Zealand & No & No & No & Yes \\
\hline 100 & Nicaragua & No & Yes & No & Yes \\
\hline 101 & Niger & Yes & Yes & Yes & Yes \\
\hline 102 & Nigeria & No & No & No & Yes \\
\hline 103 & Norway & No & No & No & Yes \\
\hline 104 & Oman & No & Yes & No & No \\
\hline 105 & Pakistan & Yes & Yes & Yes & Yes \\
\hline 106 & Panama & No & No & No & Yes \\
\hline 107 & Papua New Guinea & No & Yes & No & Yes \\
\hline 108 & Paraguay & No & Yes & No & Yes \\
\hline 109 & Peru & Yes & Yes & Yes & Yes \\
\hline 110 & Philippines & No & No & No & Yes \\
\hline 111 & Poland & No & No & No & Yes \\
\hline 112 & Portugal & No & No & No & Yes \\
\hline 113 & Qatar & No & No & No & No \\
\hline 114 & Romania & No & Yes & No & Yes \\
\hline 115 & Rwanda & No & Yes & No & Yes \\
\hline 116 & Saudi Arabia & No & No & No & Yes \\
\hline 117 & Senegal & Yes & Yes & No & Yes \\
\hline 118 & Serbia & No & Yes & No & Yes \\
\hline 119 & Sierra Leone & No & Yes & Yes & Yes \\
\hline 120 & Singapore & No & No & No & Yes \\
\hline 121 & Slovak Republic & No & Yes & No & Yes \\
\hline 122 & Slovenia & No & No & No & Yes \\
\hline 123 & Solomon Islands & No & Yes & Yes & Yes \\
\hline
\end{tabular}


Table 5 (continued)

\begin{tabular}{|c|c|c|c|c|c|}
\hline \multirow[t]{2}{*}{ ID } & \multirow[t]{2}{*}{ Country } & \multicolumn{4}{|c|}{ Variation in democracy measures } \\
\hline & & Democracy & Polity IV & DSVMDI & CSVMDI \\
\hline 124 & South Africa & No & No & No & Yes \\
\hline 125 & South Korea & No & No & No & Yes \\
\hline 126 & South Sudan & No & No & No & Yes \\
\hline 127 & Spain & No & No & No & Yes \\
\hline 128 & Sri Lanka & No & Yes & No & Yes \\
\hline 129 & Sudan & No & Yes & No & Yes \\
\hline 130 & Sweden & No & No & No & Yes \\
\hline 131 & Switzerland & No & No & No & Yes \\
\hline 132 & Syria & No & Yes & No & Yes \\
\hline 133 & Tajikistan & No & Yes & No & Yes \\
\hline 134 & Tanzania & No & No & No & Yes \\
\hline 135 & Thailand & Yes & Yes & Yes & Yes \\
\hline 136 & Togo & No & Yes & Yes & Yes \\
\hline 137 & Tunisia & Yes & Yes & Yes & Yes \\
\hline 138 & Turkey & No & Yes & No & Yes \\
\hline 139 & Turkmenistan & No & Yes & No & Yes \\
\hline 140 & UAE & No & No & No & No \\
\hline 141 & UK & No & No & No & Yes \\
\hline 142 & USA & No & No & No & Yes \\
\hline 143 & Uganda & No & Yes & Yes & Yes \\
\hline 144 & Ukraine & No & Yes & No & Yes \\
\hline 145 & Uruguay & No & No & No & Yes \\
\hline 146 & Uzbekistan & No & No & No & Yes \\
\hline 147 & Venezuela & Yes & Yes & No & Yes \\
\hline 148 & Vietnam & No & No & No & Yes \\
\hline 149 & Yemen & No & Yes & No & Yes \\
\hline 150 & Zambia & Yes & Yes & No & Yes \\
\hline 151 & Zimbabwe & No & Yes & Yes & Yes \\
\hline
\end{tabular}


Table 6 Summary statistics

(1) (2) (3)

All countries Democracies Autocracies

Government health expenditure ( $\%$ of GDP)

\begin{tabular}{|c|c|c|c|}
\hline Mean & 3.04526 & 4.233226 & 1.963151 \\
\hline Std. Dev & 2.094596 & 2.225664 & 1.195672 \\
\hline Min & .0377395 & .126284 & .0377395 \\
\hline Max & 9.419748 & 9.419748 & 7.120775 \\
\hline \multicolumn{4}{|c|}{ Private health expenditure (\% of GDP) } \\
\hline Mean & 2.530737 & 2.539681 & 2.373877 \\
\hline Std. Dev & 1.386315 & 1.309485 & 1.363227 \\
\hline Min & .1929458 & .1929458 & .3212117 \\
\hline Max & 10.07044 & 8.447127 & 8.14499 \\
\hline \multicolumn{4}{|c|}{ GDP per capita (constant 2015 USD) $(t-1)$} \\
\hline Mean & $11,785.3$ & $18,197.89$ & 7728.91 \\
\hline Std. Dev & $19,032.25$ & $22,718.84$ & $14,260.05$ \\
\hline Min & 141.0371 & 187.1638 & 141.0371 \\
\hline $\operatorname{Max}$ & $126,692.3$ & $126,692.3$ & $92,603.72$ \\
\hline \multicolumn{4}{|c|}{ Population $(t-1)$} \\
\hline Mean & $3.47 \mathrm{e}+07$ & $4.87 e+07$ & $2.01 \mathrm{e}+07$ \\
\hline Std. Dev & $1.07 \mathrm{e}+08$ & $1.48 \mathrm{e}+08$ & $2.31 \mathrm{e}+07$ \\
\hline Min & 401,538 & 401,538 & 569,447 \\
\hline Max & $1.29 \mathrm{e}+09$ & $1.29 \mathrm{e}+09$ & $9.74 \mathrm{e}+07$ \\
\hline \multicolumn{4}{|c|}{ Population ages 65 and above (\% of total) $(t-1)$} \\
\hline Mean & 7.260747 & 10.39315 & 4.164699 \\
\hline Std. Dev & 5.275388 & 5.665244 & 2.408049 \\
\hline Min & .75047 & 2.353978 & .75047 \\
\hline Max & 24.62983 & 24.62983 & 14.73545 \\
\hline \multicolumn{4}{|c|}{ Population ages $0-14$ (\% of total) $(t-1)$} \\
\hline Mean & 30.73051 & 25.43843 & 34.93673 \\
\hline Std. Dev & 10.75519 & 9.941269 & 9.265873 \\
\hline Min & 13.08418 & 13.14759 & 13.08418 \\
\hline Max & 50.22332 & 46.97504 & 49.8676 \\
\hline \multicolumn{4}{|c|}{ Globalization $(t-1)$} \\
\hline Mean & 58.62118 & 67.70784 & 50.5335 \\
\hline Std. Dev & 15.53496 & 13.42397 & 12.15156 \\
\hline Min & 23.2923 & 28.88015 & 23.29238 \\
\hline $\operatorname{Max}$ & 90.6673 & 90.6673 & 83.1516 \\
\hline \multicolumn{4}{|c|}{ Democracy $(t-1)$} \\
\hline Mean & .5793972 & .9981464 & .0013441 \\
\hline Std. Dev & .4937669 & .0430331 & .0366618 \\
\hline Min & 0 & 0 & 0 \\
\hline Max & 1 & 1 & 1 \\
\hline Polity IV $(t-$ & & & \\
\hline
\end{tabular}

$$
3.04
$$

2.094596

.0377395

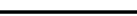

963151

1.195672

.0377395

.120775

373877

.363227

.3212117

8.14499

$3.47 \mathrm{e}+07$

$4.87 \mathrm{e}+07$

$2.01 \mathrm{e}+07$

$1.07 \mathrm{e}+08$

$2.31 \mathrm{e}+07$

69,447

$1.29 \mathrm{e}+09$

7.260747

.75047

14.73545

30.73051

25.43843

34.93673

13.08418

13.14759

49.8676

Max

67.70784

23.29238

83.1516

Democracy $(t-1)$

Mean 
Table 6 (continued)

\begin{tabular}{llll}
\hline & $(1)$ & $(2)$ & $(3)$ \\
& All countries & Democracies & Autocracies \\
\hline Mean & 3.719441 & 8.412256 & -2.995946 \\
Std. Dev & 6.236519 & 1.863102 & 4.854721 \\
Min & -10 & -2 & -10 \\
Max & 10 & 10 & 9 \\
DSVMDI $(t-1)$ & & & .2446237 \\
Mean & .6963563 & .9953661 & .430153 \\
Std. Dev & .4599341 & .0679465 & 0 \\
Min & 0 & 0 & 1 \\
Max & 1 & 1 & .3165593 \\
CSVMDI $(t-1)$ & & & .2759263 \\
Mean & .6698222 & .9171713 & .0256248 \\
Std. Dev & .3402615 & .0796217 & .9318528 \\
Min & .0256248 & .0561707 & .9736552 \\
Max & .9736552 & & \\
\hline
\end{tabular}




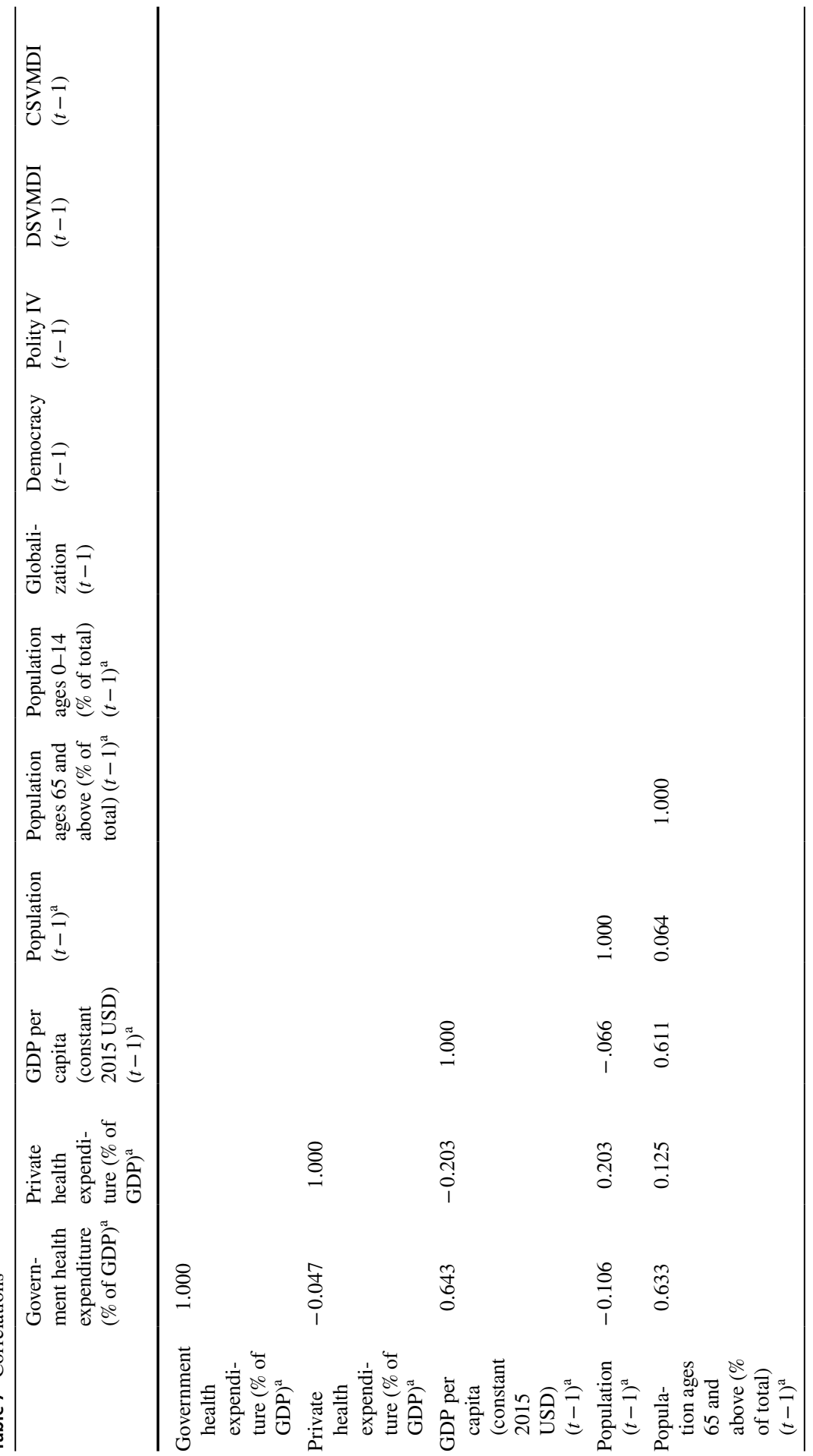




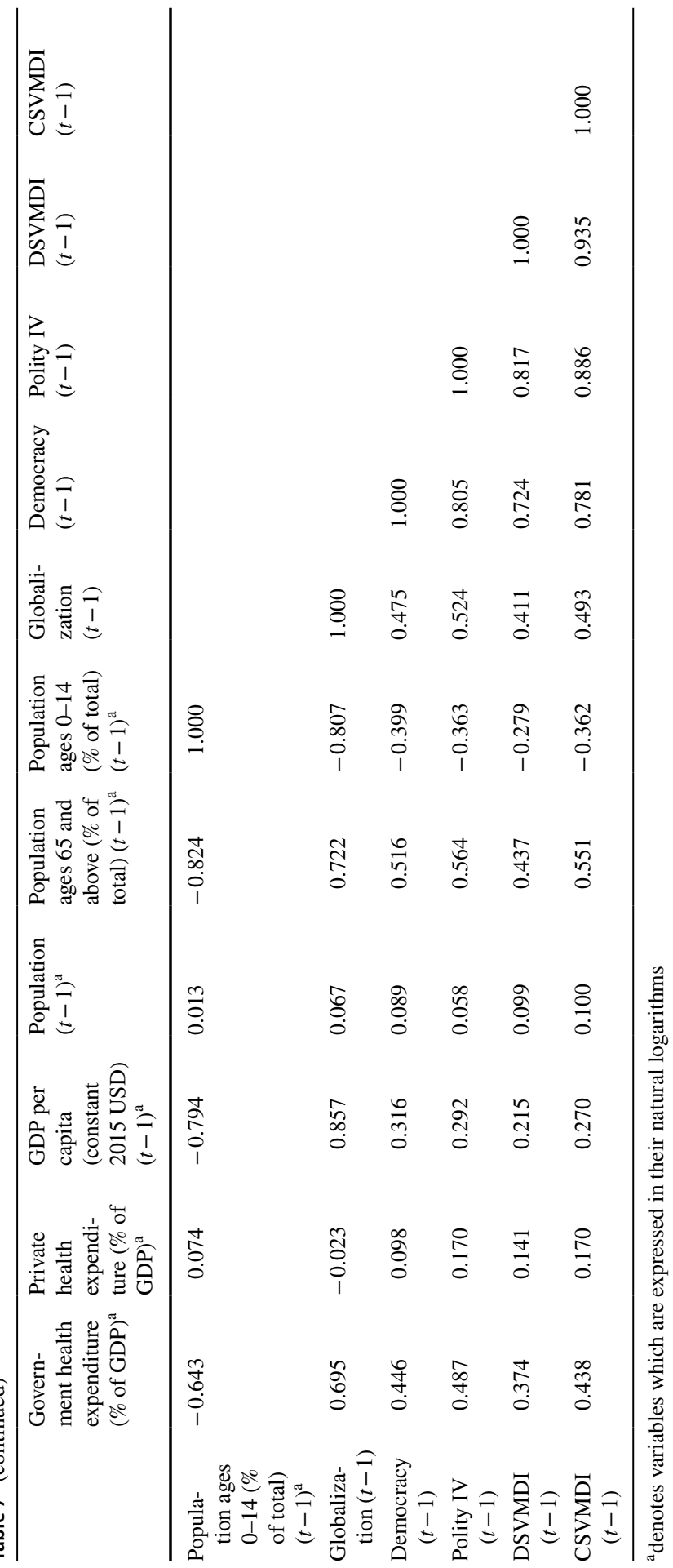


Electronic supplementary material The online version of this article (https://doi.org/10.1007/s1079 7-020-09648-9) contains supplementary material, which is available to authorized users.

Acknowledgements We thank Klaus Gründler, Niklas Potrafke, Gérard Roland, two anonymous referees, as well as the participants of the annual meeting of the European Public Choice Society (EPCS) 2019, of the annual congress of the International Institute for Public Finance (IIPF) 2019, and the 2020 workshop on the Political Economy of Democracy and Dictatorship (PEDD) for valuable comments. Florian Dorn is grateful for support from the Hanns-Seidel-Foundation.

Funding Open Access funding enabled and organized by Projekt DEAL.

\section{Compliance with ethical standards}

Conflict of interest No conflicts of interest to disclose. The views and opinions expressed in this article are those of the authors and do not necessarily reflect the views of the authors' institutions.

Open Access This article is licensed under a Creative Commons Attribution 4.0 International License, which permits use, sharing, adaptation, distribution and reproduction in any medium or format, as long as you give appropriate credit to the original author(s) and the source, provide a link to the Creative Commons licence, and indicate if changes were made. The images or other third party material in this article are included in the article's Creative Commons licence, unless indicated otherwise in a credit line to the material. If material is not included in the article's Creative Commons licence and your intended use is not permitted by statutory regulation or exceeds the permitted use, you will need to obtain permission directly from the copyright holder. To view a copy of this licence, visit http://creativecommons.org/licenses/by/4.0/.

\section{References}

Acemoglu, D., Naidu, S., Restrepo, P., \& Robinson, J. A. (2019). Democracy does cause growth. Journal of Political Economy, 127(1), 47-100.

Acemoglu, D., \& Robinson, J. A. (2006). Economic origins of dictatorship and democracy. Cambridge: Cambridge University Press.

Aidt, T., \& Jensen, P. (2014). Workers of the world, unite! franchise extensions and the threat of revolution in Europe, 1820-1938. European Economic Review, 72, 52-75.

Alvarez, M., Cheibub, J. A., Limongi, F., \& Przeworski, A. (1996). Classifying political regimes. Studies in Comparative International Development, 31(2), 3-36.

Avelino, G., Brown, D. S., \& Hunter, W. (2005). The effects of capital mobility, trade openness, and democracy on social spending in Latin America, 1980-1999. American Journal of Political Science, 49(3), 625-641.

Barros, P. (1998). The Black-box of health care expenditure growth determinants. Health Economics, 7, 533-544.

Bergh, A., \& Nilsson, T. (2010). Good for living? On the relationship between globalization and life expectancy. World Development, 38(9), 1191-1203.

Besley, T., \& Kudamatsu, M. (2006). Health and democracy. American Economic Review, 96(2), 313-318.

Bjørnskov, C., \& Rode, M. (2019). Regime types and regime change: A new dataset on democracy, coups, and political institutions. The Review of International Organizations, forthcoming.

Blum, J. (2021). Democracy's third wave and national defense spending. Public Choice, forthcoming. https://doi.org/10.1007/s11127-020-00870-x.

Bonhomme, S., \& Manresa, E. (2015). Grouped patterns of heterogeneity in panel data. Econometrica, 83(3), 1147-1184.

Bove, V., Efthyvoulou, G., \& Navas, A. (2017). Political cycles in public expenditure: Butter vs guns. Journal of Comparative Economics, 45(3), 582-604.

Cheibub, J. A., Gandhi, J., \& Vreeland, J. R. (2010). Democracy and dictatorship revisited. Public Choice, 143, 67-101. 
Deacon, R. T. (2009). Public good provision under dictatorship and democracy. Public Choice, 139, $241-262$.

Deaton, A. S. (2004). Health in an age of globalization. In S. M. Collins \& C. Graham (Eds.), Brookings trade forum (pp. 83-130). Washington D. C: Brookings Institution Press.

Dorn, F., Fuest, C., \& Potrafke, N. (2018) Globalization and income inequality revisited. CESifo Working Paper No. 6859.

Dorn, F., \& Schinke, C. (2018). Top income shares in OECD countries: The role of government ideology and globalization. The World Economy, 41(9), 2491-2527.

Dreher, A., Sturm, J.-E., \& Ursprung, H. W. (2008). The impact of globalization on the composition of government expenditures: Evidence from panel data. Public Choice, 134(3-4), 263-292.

Ellis, C. J., \& Fender, J. (2011). Information cascades and revolutionary regime transitions. The Economic Journal, 121(553), 763-792.

Gallup, J. L., Sachs, J. D., \& Mellinger, A. D. (1999). Geography and economic development. In B. Pleskovic \& J. E. Stiglitz (Eds.), World bank annual conference on development economics 1998 (pp. 127-178). Washington D. C.: The World Bank.

Gerdtham, U.-G. (1992). Pooling international health care expenditure data. Health Economics, 1(4), 217-231.

Gregorio, L., \& Gregorio, D. (2013). Polity and health care expenditures: The association among 159 nations. Journal of Epidemiology and Global Health, 3(1), 49-57.

Gründler, K., \& Köllner, S. (2017). Determinants of governmental redistribution: income distribution, development levels, and the role of perceptions. Journal of Comparative Economics, 45(4), 930-962.

Gründler, K., \& Krieger, T. (2016). Democracy and growth: Evidence from a machine learning indicator. European Journal of Political Economy, 45, 85-107.

Gründler, K., \& Krieger, T. (2018). Machine learning indices, political institutions, and economic development. CESifo Working Paper No. 6930.

Gygli, S., Haelg, F., Potrafke, N., \& Sturm, J.-E. (2019). The KOF globalization index-revisited. Review of International Organizations, 14(3), 543-574.

Habibi, N. (1994). Budgetary policy and political liberty: A cross-sectional analysis. World Development, 22(4), 579-586.

Hausken, K., Martin, C. W., \& Plümper, T. (2004). Government spending and taxation in democracies and autocracies. Constitutional Political Economy, 15(3), 239-259.

Huntington, S. P. (1991a). The third wave: democratization in the late Twentieth century. Norman: University of Oklahoma Press.

Huntington, S. P. (1991b). Democracy's third wave. Journal of Democracy, 2(2), 12-34.

Justesen, M. K. (2012). Democracy, dictatorship, and disease: Political regimes and HIV/AIDS. European Journal of Political Economy, 28(3), 373-389.

Klomp, J., \& de Haan, J. (2009). Is the political system really related to health? Social Science and Medicine, 69(1), 36-46.

Kudamatsu, M. (2012). Has democratization reduced infant mortality in Sub-Saharan Africa? Evidence from micro data. Journal of the European Economic Association, 10(6), 1294-1317.

Lake, D. A., \& Baum, M. A. (2001). The invisible hand of democracy: Political control and the provision of public services. Comparative Political Studies, 34(6), 587-621.

Lipset, S. M. (1959). Some social prerequisites for democracy: economic development and political legitimacy. American Political Science Review, 53, 69-105.

Marshall, M. G., Gurr, T. R., \& Jaggers, K. (2018). Polity IV project. Political regime characteristics and transitions, 1800-2017. Dataset Users' Manual. Center for systemic peace.

McGuire, M. C., \& Olson, M. (1996). The economics of autocracy and majority rule: The invisible hand and the use of force. Journal of Economic Literature, 34(1), 72-96.

Meltzer, A., \& Richard, S. (1981). A rational theory of the size of government. Journal of Political Economy, 89(5), 914-927.

Mulligan, C., Gil, R., \& Sala-i-Martin, X. (2004). Do democracies have different public policies than nondemocracies? Journal of Economic Perspectives, 18(1), 51-74.

Papaioannou, E., \& Siourounis, G. (2008). Democratization and growth. The Economic Journal, 118, $1520-1551$.

Plümper, T., \& Martin, C. W. (2003). Democracy, government spending, and economic growth: A political-economic explanation of the Barro-Effect. Public Choice, 117(1/2), 27-50. 
Plümper, T., \& Neumayer, E. (2010). The level of democracy during interregnum periods: recoding the polity2 score. Political Analysis, 18, 206-226.

Potrafke, N. (2012). Islam and democracy. Public Choice, 151, 185-192.

Potrafke, N. (2013). Democracy and countries with Muslim majorities: a reply and update. Public Choice, 154, 323-332.

Potrafke, N. (2015). The evidence on globalisation. The World Economy, 38(3), 509-552.

Profeta, P., Puglisi, R., \& Scabrosetti, S. (2013). Does democracy affect taxation and government spending? Evidence from developing countries. Journal of Comparative Economics, 41, 684-718.

Roberts, J. (1999). Sensitivity of elasticity estimates for OECD health care spending: analysis of a dynamic heterogeneous data field. Health Economics, 8(5), 459-472.

Solt, F. (2016). The standardized world income inequality database. Social Science Quarterly, 97(5), 1267-1281.

Stock, J., \& Yogo, M. (2005). Testing for weak instruments in linear IV regression. In D. Andrews \& J. Stock (Eds.), Identification and inference for econometric models: essays in honour of Thomas Rothenberg (pp. 80-108). Cambridge: Cambridge University Press.

Welander, A., Lyttkens, C. H., \& Nilsson, T. (2015). Globalization, democracy, and child health in developing countries. Social Science and Medicine, 136-137, 52-63.

Publisher's Note Springer Nature remains neutral with regard to jurisdictional claims in published maps and institutional affiliations. 